\title{
Characterization of Tissue Plasminogen Activator Expression and Trafficking in the Adult Murine Brain
}

\author{
(1DTamara K. Stevenson, ${ }^{1}$ and ${ }^{1}$ Daniel A. Lawrence ${ }^{1,2}$
}

DOI:http://dx.doi.org/10.1523/ENEURO.0119-18.2018

${ }^{1}$ Department of Molecular and Integrative Physiology, University of Michigan Medical School, Ann Arbor, Ml 48109 and ${ }^{2}$ Department of Internal Medicine, Division of Cardiovascular Medicine, University of Michigan Medical School, Ann Arbor, MI 48109

\begin{abstract}
Tissue plasminogen activator (tPA) is an immediate-early gene important for regulating physiological processes like synaptic plasticity and neurovascular coupling. It has also been implicated in several pathological processes including blood-brain barrier (BBB) permeability, seizure progression, and stroke. These varied reports suggest that LPA is a pleiotropic mediator whose actions are highly compartmentalized in space and time. The specific localization of tPA, therefore, can provide useful information about its function. Accordingly, the goal of this study was to provide a detailed characterization of tPA's regional, cellular, and subcellular localization in the brain. To achieve this, two new transgenic mouse lines were utilized: (1) a Plat $\beta G A L$ reporter mouse, which houses the $\beta$-galactosidase gene in the tPA locus and (2) a tPA ${ }^{\text {BAC }}$-Cerulean mouse, which has a cerulean-fluorescent protein fused in-frame to the tPA C-terminus. Using these two transgenic reporters, we show that while tPA is expressed throughout most regions of the adult murine brain, it appears to be preferentially targeted to fiber tracts in the limbic system. In the hippocampus, confocal microscopy revealed tPA-Cerulean (tPA-Cer) puncta localized to giant mossy fiber boutons (MFBs) and astrocytes in stratum lucidum. With amplification of the tPA-Cer signal, somatically localized tPA was also observed in the stratum oriens (SO)/alveus layer of both CA1 and CA3 subfields. Coimmunostaining of tPA-Cer and interneuronal markers indicates that these tPA-positive cell bodies belong to a subclass of somatostatin (SST)/oriens-lacunosum moleculare (O-LM) interneurons. Together, these data imply that tPA's localization is differentially regulated, suggesting that its neuromodulatory effects may be compartmentalized and specialized to cell type.
\end{abstract}

Key words: gene expression; interneuron; mossy fibers; protein-traffiking; somatostatintPA

\section{Significance Statement}

The serine protease tissue plasminogen activator (tPA) has been shown to modulate numerous neurologic processes including synaptic plasticity and neurodegeneration. Many of the functional conclusions drawn about tPA activity, however, have not been affirmed by high-resolution, imaging analysis of tPA localization. To address these shortcomings, we used two new transgenic reporter mice to provide a detailed characterization of tPA expression in the adult murine brain. A comparison of these reporter mice demonstrates a differential expression pattern between the sites of tPA synthesis and its targeted localization in the hippocampus, amygdala, and basal ganglia. Moreover, colocalization and coexpression analysis reveals that tPA is primarily trafficked to presynaptic structures and that it's predominant somatic and/or axonal localization is cell-type specific.

Received March 27, 2018; accepted July 2, 2018; First published July 17, 2018.

The authors declare no competing financial interests.
Author contributions: T.K.S. and D.A.L. designed research; T.K.S. performed research; T.K.S. and D.A.L. analyzed data; T.K.S. wrote the paper. 


\section{Introduction}

Tissue plasminogen activator (tPA) is a serine protease expressed in vascular endothelial cells with a wellestablished role in fibrinolysis. Biomechanistic understanding of tPA's fibrinolytic function led to the development of recombinant IPA (rtPA) as a thrombolytic agent, and the current standard of care for moderate to severe ischemic stroke is thrombolytic therapy with rtPA (Prabhakaran et al., 2015). However, beyond 3-4.5 h following stroke onset, thrombolytic efficacy is diminished, and there is an increased risk of hemorrhagic conversion, limiting the therapeutic window for rtPA administration (Ahmed et al., 2010; Sandercock et al., 2012). The molecular mechanisms responsible for the increased risk of hemorrhage are thought, in part, to occur from exogenously administered rtPA crossing the ischemic, compromised blood-brain barrier (BBB) and acting through endogenous tPA-mediated signaling pathways on the abluminal side of the vasculature in the CNS to induce BBB opening (Su et al., 2008).

In addition to BBB regulation (Fredriksson et al., 2015) parenchymal brain tPA has been reported to be involved in other processes in the CNS, including neurite outgrowth (Krystosek and Seeds, 1981), regeneration (Akassoglou et al., 2000; Zou et al., 2006), synaptic transmission and synaptic plasticity (Wu et al., 2015; Frey et al., 1996; Huang et al., 1996), excitotoxic injury (Tsirka et al., 1995; Nicole et al., 2001; Siao et al., 2003), and neurovascular coupling (Park et al., 2008). One of the earliest studies implicating tPA in a non-fibrinolytic function found the serine protease to be an immediate-early gene that is upregulated in the hippocampus following seizures, kindling, and long-term potentiation (LTP; Qian et al., 1993), suggesting a proteolytic mechanism for activity-dependent structural changes at the synapse. Subsequent in situ hybridization studies showed tPA mRNA expression predominantly in hippocampal pyramidal and granule cell layers, and the granule cell layer of the cerebellum (Sappino et al., 1993).

While gross anatomic localization studies of tPA protein and protease activity have consistently shown IPA in the hilus and stratum lucidum layer of the hippocampus (Sappino et al., 1993; Salles and Strickland, 2002), more detailed cellular localization studies of tPA protein expression have been inconsistent (Fredriksson et al., 2015; Louessard et al., 2016). tPA-immunoreactivity, following colchicine treatment to block axo-dendritic transport, has been reported in glutamatergic cortical neurons and in the pyramidal and granule

This work was supported by National Institutes of Health Grants HL055374 and NS079639 (to D.A.L.) and T32-HL125242 and T32-GM008322 (T.K.S.).

Acknowledgments: We thank Kris Mann and Mark Warnock for excellent technical assistance and the University of Michigan Transgenic Core for their expertise in the generation of BAC transgenic animals. We also thank Geoffrey Murphy, Edward Stuenkel, Shannon Moore, Kasia Glanowska, and Victor Cazares for their critical reading of this manuscript.

Correspondence should be addressed to Daniel A. Lawrence, Department of Internal Medicine, University of Michigan Medical School, 7301 MSRB III, 1150 W. Medical Center Drive, Ann Arbor, Ml 48109-5644, E-mail: dlawrenc@umich.edu. DOI:http://dx.doi.org/10.1523/ENEURO.0119-18.2018

Copyright $\odot 2018$ Stevenson and Lawrence

This is an open-access article distributed under the terms of the Creative Commons Attribution 4.0 International license, which permits unrestricted use, distribution and reproduction in any medium provided that the original work is properly attributed. cell layers of the hippocampus (Louessard et al., 2016). In contrast, Fredriksson et al. (2015) primarily detected tPAimmunoreactivity in endothelial cells and a subset of perivascular interneurons. At the subcellular level, tPA appears to have a polarized distribution, as it has been localized to dense core vesicles in both presynaptic (Silverman et al., 2005; Scalettar et al., 2012) and postsynaptic (Lochner et al., 1998; Shin et al., 2004; Lochner et al., 2006) compartments; although these studies were done in vitro using clonal neuroendocrine cell lines or primary hippocampal neurons.

These disparate findings on localization of tPA have complicated and contributed to the multivariate hypotheses that exist regarding tPA's function in the CNS. To address some of these discrepancies, we have used two transgenic mouse strategies: (1) a Plat $\beta G A L$ reporter mouse, which has the $\beta$-galactosidase gene knocked-in to the tPA gene, Plat, and (2) a tPA ${ }^{\mathrm{BAC}_{-}}$-Cerulean (tPA ${ }^{\mathrm{BAC}}$ Cer) fusion mouse, which has a cerulean-fluorescent protein fused to tPA. The $\mathrm{TPA}^{\mathrm{BAC}}$-Cer mice were generated using bacterial artificial chromosome (BAC) technology. Critically, large transgene vectors, like BACs, are more likely than smaller plasmids to produce copy-number dependent transgene expression, and thereby, recapitulate endogenous gene expression patterns (Van Keuren et al., 2009). In parallel analysis of coronal sections from Plat $\beta G A L$ and $\mathrm{TPA}^{\mathrm{BAC}}$-Cer mice, our results demonstrate that tPA's protein localization is uncoupled from its site of synthesis. This differential expression pattern is most prominent in the hippocampus, but it is also pronounced in the amygdala and basal ganglia. Moreover, using highresolution confocal microscopy, in the hippocampus we found tPA to be localized to giant mossy fiber boutons (MFBs) and astrocytes in stratum lucidum and somatically localized to interneurons in stratum oriens (SO)/alveus. Coexpression analysis indicates that these tPA-positive cell bodies in the hippocampus belong to a subset of somatostatin (SST)/oriens-lacunosum moleculare (O-LM) inhibitory interneurons. These results suggest that tPA is differently trafficked and positioned to have diverse modulatory effects on synaptic efficacy based on cell type and subcellular localization.

\section{Materials and Methods}

\section{Transgenic mice}

tPA ${ }^{B A C}$-Cerulean transgenic mice

Founder lines (863 and 876 ) for $\mathrm{TPA}^{\mathrm{BAC}}$-Cer transgenic mice were generated using $B A C$ technology. To generate tPA $^{\mathrm{BAC}}$-Cer transgenic mice, exon 14 of the tPA gene, Plat, on a $162.524 \mathrm{~kb}$ BAC acquired from chori.org (RP23259A10), was replaced with a cerulean fluorescent gene (Rizzo et al., 2004) fused to the C-terminus of exon 14 of the murine tPA gene (NM_008872.2) followed by a bovine growth hormone polyadenylation signal sequence. The tPA-Cerulean (tPA-Cer) fusion gene is under control of the endogenous regulatory elements contained in the Plat locus. BAC DNA integrity was verified by restriction enzyme analysis via pulse field gel electrophoresis and exon sequencing before pronuclear microinjection of supraovulated eggs from (C57BL/6 $\times$ SJL)F1/TAC female mice. 
Transgenic mice were genotyped by PCR using primers that were specific to a remnant of the sub-cloning PGKneo vector and the tPA-Cer fusion gene (FWD 5'-CAT GAA GCA AGG ATC CAT GG-3', and REV 5'-GGA ACT TCG CGG CCG CAG C-3'); and IPA protein expression was confirmed by analysis of brain homogenates from the founder lines. After PCR analysis of the cerulean fusion gene confirmed stable, germline transmission in $\mathrm{F} 1$ pups two founder lines, lines 863 and 876, were propagated; these mice were then backcrossed at least eight generations onto a C57BL/6J genetic background. Transgenic mice displayed normal gross anatomy and a Mendelian inheritance pattern.

\section{Plat $\beta G A L$ reporter mice}

The Plat $\beta$ GAL mice were acquired from the UC Davis Knockout Mouse Project (KOMP) Repository (Project ID: VG15085) on a C57BL/6NTac background. Plat $\beta$ GAL mice were then backcrossed onto a C57BL/6J background for at least 10 generations. Per the KOMP Repository, Plat $\beta G A L$ mice were generated by inserting a LacZcontaining targeting vector between exon 2 and 14 to produce a null allele. The insertion sites of the Plat $\beta$ GAL mice were sequenced to confirm the appropriate insertion of the LacZ gene in the Plat locus.

All animals were housed in a controlled environment and were provided with food and water ad libitum. All animal experiments were approved by a local committee at the University of Michigan, and the studies were conducted in accordance with the United States Public Health Services Policy on Humane Care and Use of Laboratory Animals.

\section{Protein expression analysis \\ Sample preparation}

Total tPA protein and enzymatic activity were analyzed using whole-brain homogenates from $\mathrm{TPA}^{\mathrm{BAC}}$-Cer mice. The total and active tPA values from tPA $^{\mathrm{BAC}}$-Cer transgene-positive mice were normalized to transgene negative littermate controls for each experimental run. Two independent experiments were conducted for a combined total of six to seven mice per transgenic line. Briefly, brains were harvested into ice-cold extraction buffer [0.4 $\mathrm{M}$ HEPES, $0.1 \mathrm{M} \mathrm{NaCl}(\mathrm{pH} 7.4)$, and $1 \%$ Triton X-100], homogenized for $1 \mathrm{~min}$. $(2 \times 30 \mathrm{~s})$ and centrifuged at $10,000 \times g$ for $10 \mathrm{~min}$. The supernatant was removed to a new, chilled $1.5-\mathrm{ml}$ microcentrifuge tube and centrifuged again at $10,000 \times g$ for $10 \mathrm{~min}$. The supernatant was again removed to a new, chilled $1.5-\mathrm{ml}$ microcentrifuge tube and used for ELISA, Luminex, and SDS-PAGE zymography assays.

\section{ELISA}

An ELISA was performed to measure tPA activity from brain tissue extracts. Briefly, avidin-coated microtiter plates (Molecular Innovations, AVI-PLATE) were incubated with a biotin-conjugated PAl-1 capture $(1 \mu \mathrm{g} / \mathrm{ml}$; Molecular Innovations, NTBIOCPAI) for $30 \mathrm{~min}$ at room temperature. After which, $100 \mu \mathrm{l}$ of brain extract samples were loaded onto the plate and incubated for $1 \mathrm{~h}$ at room temperature. A rabbit anti-human tPA ( $3 \mu \mathrm{g} / \mathrm{ml}$; Molecular Innovations, ASHTPA-GF) was used as the primary antibody and a donkey anti-rabbit HRP (1:5000; Jackson ImmunoResearch, 711-036-152) was used as the secondary. All sample and antibody incubations were followed by three washes of PBS-0.05\% Tween 20. After the final wash, 3,3',5,5'-tetramethylbenzidine (TMB) substrate (Molecular Innovations, TMB) was added to each sample for $3 \mathrm{~min}$ at room temperature. $\mathrm{H}_{2} \mathrm{SO}_{4}(1 \mathrm{~N})$ was then added and the plate read on a spectrophotometer at $450 \mathrm{~nm}$.

\section{Luminex}

To measure total murine tPA protein from $\mathrm{tPA}^{\mathrm{BAC}}-\mathrm{Cer}$ brain extracts, $50 \mu \mathrm{g}$ of Rabbit anti-murine tPA (mtPA; Molecular Innovations, ASMTPA-GF-HT) was coupled to Luminex carboxylated beads for mtPA capture. Standards of known concentration of murine tPA (Molecular Innovations, MTPA) and brain extract samples (diluted in $0.4 \mathrm{M} \mathrm{HEPES}, 0.1 \mathrm{M} \mathrm{NaCl}(\mathrm{pH} 7.4)$, and $1.0 \%$ Triton X-100] were loaded onto a 96 well filter plate (Millipore) and incubated with 5000 beads [PBS-1.0\% bovine serum albumin (BSA)] for $2 \mathrm{~h}$ at room temperature in the dark. The solution from was removed from each well and washed twice with PBS-0.05\% Tween 20 . The beads were then mixed with continuous shaking in the dark at room temperature for $1 \mathrm{~h}$ with $2 \mu \mathrm{g} / \mathrm{ml}$ biotin-labeled rabbit antimouse tPA-high titer (Molecular Innovations, ASHTPA$\mathrm{HT}$ ), after which $10 \mu \mathrm{g} / \mathrm{ml}$ of Streptavidin, R-Phycoerythrin (ThermoFisher Scientific, S866) was added to each well for $1 \mathrm{~h}$. The solution was removed from each well, and the beads were washed three times with PBS-0.05\% Tween 20 , and, lastly, sheath fluid was added for $5-10 \mathrm{~min}$. The beads were then read with the Luminex 100 (medium setting; $10-\mu$ l sample size; 100 events/bead).

\section{SDS-PAGE zymographies}

Gel electrophoresis and zymography were performed as previously described (Huarte et al., 1985). Briefly, $1 \mu \mathrm{g}$ of protein from homogenized whole-brain tissue extracts from transgene-positive and transgene-negative $\mathrm{PA}^{\mathrm{BAC}}$ Cer mice were loaded onto an in-house prepared $10 \%$ polyacrylamide gel with plasminogen $\left([10.0 \mu \mathrm{g} / \mathrm{ml}]_{\mathrm{FINAL}}\right)$ and casein $\left([1.0 \mathrm{mg} / \mathrm{ml}]_{\mathrm{FINAL}}\right)$. Samples were run for $30 \mathrm{~min}$ at $100 \mathrm{~V}$ through the stacking gel and $200 \mathrm{~V}$ for $40 \mathrm{~min}$ through the running gel. Gel was washed $4 \times 30 \mathrm{~min}$ in $2.5 \% \mathrm{Tx}-100\left(\mathrm{dH}_{2} \mathrm{O}\right)$ and then briefly washed for $5 \mathrm{~min}$ in $0.1 \mathrm{M}$ Tris buffer $(\mathrm{pH}$ 8.1) before developing in $0.1 \mathrm{M}$ Tris buffer at $37^{\circ} \mathrm{C}$ for $4 \mathrm{~h}$. Gels were stained with Bio-Safe Coomasie (Bio-Rad, 1610786); bands devoid of stain indicate areas of proteolytic activity.

\section{Immunofluorescence and histochemical analysis Immunofluorescence analysis}

Mice were anesthetized with isoflurane and sacrificed by transcardiac perfusion for 3 min with PBS followed by perfusion for $5 \mathrm{~min}$ with $4 \%$ paraformaldehyde (PFA). Brains were harvested and postfixed in 4\% PFA for $1 \mathrm{~h}$ at $4^{\circ} \mathrm{C}$, then overnight in PBS. The brains were then moved to a $30 \%$ sucrose solution and kept at $4^{\circ} \mathrm{C}$ till submerged. Subsequently, dorsal hippocampal sections (14 and 50 $\mu \mathrm{m})$ and serial sections ( $14 \mu \mathrm{m}$, bregma +1.0 to bregma -8.0) were cut coronally for immunofluorescence analysis of tPA expression. When using the Rabbit anti-mtPA antibody, sections underwent antigen retrieval (DAKO, 
S1700); the additional antigen retrieval step was not necessary for other antibodies. Sections were permeabilized with $0.50 \%$ Triton $\mathrm{X}-100$ (PBS) for $20 \mathrm{~min}$ at room temperature and blocked in 3\% BSA (PBS) for $1 \mathrm{~h}$ at room temperature. The sections were then incubated with primary antibodies in $2 \%$ BSA (PBS) overnight at $4^{\circ} \mathrm{C}$, followed by incubation with secondary antibodies in $2 \%$ BSA (PBS) for 1 $\mathrm{h}$ at room temperature. When using biotin-conjugated primary antibodies and their respective streptavidin-conjugated secondary was used, a biotin-blocking kit was used to reduce background (ThermoFisher Scientific, E21390). For amplification using the Tyramide SuperBoost kit (ThermoFisher Scientific, B40932) detection protocols were followed according to the manufacturer's instructions.

The primary antibodies used were as follows: calbindin D28K (rabbit anti-calbindin, 1:500; Synaptic Systems, 214002; lot \#214002/3), microtubule-associated protein 2 (rabbit anti-MAP2, 1:1000; Millipore, AB5622; lot \#2624211), zinc transporter 3 (guinea pig anti-ZnT3, 1:500; Synaptic Systems, 197004; lot \#197004/4), excitatory amino acid transporter 2 (rabbit anti-EAAT2, 1:500; Synaptic Systems, 250203; lot \#250203/3), GFP (chicken anti-GFP, 1:1000; abcam, ab13970; lot \#GR236651-7 and GR236651-14), NeuN (guinea pig anti-NeuN, 1:400; Synaptic Systems 266004; lot \#266004/2-14 and 266004/7), GAD65 (guinea pig antiGAD65, 1:500; Synaptic Systems 198104; lot \#198104/7), murine tPA (rabbit anti-mtPA, $12 \mu \mathrm{g} / \mathrm{ml}$; Molecular Innovations, ASMTPA-GF-HT; lot \#804 and 914), metabotropic glutamate receptor type 1a (rabbit anti-mGluR1a, 1:200; Sigma, G9665; lot \#SLBL4165V), SST (rat anti-SST, 1:100; Millipore, MAB354; lot \#2885355, 3005269), CD31 (rat antimCD31, 1:100; BD Biosciences, 550274; lot \#21055). The secondary antibodies used were as follows: biotinconjugated goat anti-chicken IgY H\&L (1:100; abcam, ab6876), goat anti-guinea pig IgG $(H+$ L) 568 (1:500; ThermoFisher Scientific, A-11075), donkey anti-rabbit IgG $(\mathrm{H}+$ L) 568 (1:500; ThermoFisher Scientific, A-10042), donkey anti-guinea Pig IgG (H + L) 594 (1:500; Jackson ImmunoResearch, 706-585-148), donkey anti-rat lgG (H + L) 594 (1: 500; ThermoFisher Scientific, A-21209), donkey anti-rabbit IgG (H + L) 594 (1:500; ThermoFisher Scientific, A-21207), tyramide-conjugated Alexa Fluor 488 (ThermoFisher Scientific, B40953). The sections were mounted using VectaShield anti-fade mounting medium (Vector Laboratories, $\mathrm{H}-1000)$.

\section{5-Bromo-4-chloro-3-indolyl- $\beta$ - $D$-galactoside analysis}

Heterozygous, homozygous, and wild-type Plat $\beta \mathrm{GAL}$ mice (mice, $n=3-5$ per genotype) were used to examine the regional somatic expression of tPA. Homozygous Plat $\beta$ GAL mice, which are null for tPA with two copies of the $\beta$-Gal gene, served as control mice for immunohistochemical stains that used an antibody directed against mtPA. Plat $\beta$ GAL mice were anesthetized with isoflurane and sacrificed by transcardiac perfusion for 3 min with PBS and 1 min with 2\% PFA, and postfixed in 2\% PFA for $1 \mathrm{~h}$ at $4^{\circ} \mathrm{C}$. Brains were then cryopreserved and sectioned by microtome. Dorsal hippocampal sections and serial sections (50 $\mu \mathrm{m}$, bregma +1.0 to bregma -8.0) were stained and analyzed for LacZ reporter gene expression using the $\beta$-Galactosidase Reporter Gene Staining kit (Sigma, GALS).

\section{Image acquisition, processing, and analysis \\ Widefield and confocal microscopy}

For Plat $\beta G A L$ and $\mathrm{tPA}^{\mathrm{BAC}}$-Cer transgenic mice, lowresolution images were acquired on an inverted Nikon Te2000 widefield microscope equipped with a MicroPublisher 5.0 RTV color camera and a CoolSNAP HQ2 CCD camera or an inverted Ti Nikon widefield microscope with an ANDOR Zyla sCMOS camera. High-resolution fluorescent images of the dorsal hippocampus in PAA $^{\mathrm{BAC}}-\mathrm{Cer}$ transgenic mice were taken using an upright confocal laser scanning microscope (Leica SP5X). The SP5X is equipped with an acousto-optical beam splitter (AOBS) and a tunable white-light laser; accordingly, the following Ex/Em combinations were used: Cerulean (458/468-558) and Alexa Fluor 568 (568/578-720); and Alexa Fluor 488 (488/498-584) and Alexa Fluor 594 (594/604-750). Images were acquired with a $20 \times$ multi-immersion objective or a $63 \times$ oil objective [Plan-Apo, 1.4 numerical aperture (NA)] at a scanning rate of $200 \mathrm{~Hz}$ with $4 \times$ line averaging at $2 \times$ or $4 \times$ optical zoom. Each frame consists of $512 \times 512$ pixels or $1024 \times 1024$ pixels. Z-stacks were collected at $0.5-$ or $1-\mu \mathrm{m}$ increments, ranging in total thickness from 5.0 to $35 \mu \mathrm{m}$, respectively, with the pinhole set to 1 Airy unit.

\section{Image processing and colocalization analysis}

Widefield images $(4 \times, 10 \times, 20 \times$, or $40 \times$ objectives) of hippocampal and serial sections from Plat $\beta$ GAL mice and tPA $^{\mathrm{BAC}}$-Cer transgene-positive and transgene-negative mice were stitched using MetaMorph Image Analysis software or Nikon's NIS-Elements Advanced Research software package, respectively. Further processing was done using the open source image processing package FIJI (Schindelin et al., 2012). Confocal images are presented as either maximum intensity projections, orthongonal slices, or 3D maximum projections using FIJI's 3D viewer (Schmid et al., 2010).

Subcellular colocalization analysis of tPA-Cer puncta in stratum lucidum was performed using the JACoP (Just Another Colocalization Plugin) analysis software in FIJI (Bolte and Cordelières, 2006). Images were concatenated from 5 - $\mu \mathrm{m}$ z-stacks $(\Delta \mathrm{z}=0.5 \mu \mathrm{m})$ that were independently acquired two to four times (ZnT3: mice $n=10$, lines 863 and 876; EAAT2: mice $n=6-8$, lines 863 and 876 , respectively; MAP2: mice $n=4$, lines 863 and 876). Manders coefficient and Costes randomization control were used to quantify tPA-Cer colocalization (Costes et al., 2004; Bolte and Cordelières, 2006; Dunn et al., 2011). The Manders coefficient was chosen because it is a more sensitive measure of colocalization for partial colocalization events and when there are large differences in fluorescent intensity between fluorophores (Bolte and Cordelières, 2006; Dunn et al., 2011). The Manders coefficient, which does not mathematically take into account average fluorophore intensity values, ranges from 0 to 1 , with 0 corresponding to no overlap and 1 to complete overlap. Two coefficients are given: M1 and M2, where $\mathrm{M} 1$ is the summed intensities of fluorophore 1 that are 
coincident with fluorophore 2, divided by the total intensity of fluorophore $1 ; \mathrm{M} 2$ is calculated the same but for fluorophore 2. Costes randomization control provides a statistical assessment of whether or not observed colocalization events could be expected to occur by chance. It is calculated by comparing the coincidence of colocalization in an original image against the coincidence of colocalization in a randomized imaged of shuffled pixels (200 times). Costes approach is expressed as a percentage; a probability $p$ value of $\geq 95 \%$ suggests that colocalization is significant and not random (Costes et al., 2004).

Cell count of tPA-Cer and SST-positive cell bodies was performed in the dorsal hippocampus of $\mathrm{tPA}^{\mathrm{BAC}}-\mathrm{Cer}$ transgenic mice over an approximate $500-\mu \mathrm{m}$ range from -2.0 to -2.5 bregma. tPA-Cer and SST-positive cells were counted manually using the ROI Manager in FIJl. Cells were deemed positive if their mean pixel intensity was 1 SD above the mean pixel intensity for the image (Liao et al., 2016). Cell count data were gathered from two to four hippocampal sections per mouse (mice, $n=8$ ) for each of $\mathrm{TPA}^{\mathrm{BAC}}$-Cer transgenic lines and their transgene negative littermate controls. Cell count data were averaged per mouse and statistics were generated using GraphPad Prism, version 7.0. Data are presented as the mean $\pm 95 \%$ confidence interval $\left[\mathrm{Cl}_{(0.95)}\right]$ of tPA-Cerexpressing cells from SO/alveus (CA1 and CA3, respectively) and stratum radiatum (SR)/stratum pyramidale (SP; $\mathrm{CA} 1$ and $\mathrm{CA} 3)$. The percentage mean $\pm \mathrm{Cl}_{(0.95)}$ of $\mathrm{tPA}-\mathrm{Cer}$ cells that coexpress SST and the percentage mean \pm $\mathrm{Cl}_{(0.95)}$ of SST-positive cells that coexpress tPA-Cer is also given. Immunohistochemical analysis of tPA-Cer cell bodies that coexpress markers of O-LM interneurons was gathered from stainings from four to eight mice per coexpression marker.

\section{Experimental design and statistical analysis}

Experimental design, including all critical variables for independent replication, is described in detail in the Materials and Methods for each experiment. Briefly, for all analysis using Plat $\beta G A L$ and $\mathrm{PPA}^{\mathrm{BAC}}$-Cer transgenic mice, a mixture of adult male and female mice was used (age, $12-45$ weeks). Wild-type Plat $\beta$ GAL littermates were used as controls for $\beta$-Gal stains, while homozygous Plat $\beta$ GAL littermates were used as controls for immunoreactivity against tPA. When evaluating global protein expression or using antibodies directed against GFP, tPA $^{\mathrm{BAC}}$-Cer transgene negative littermates were used as controls. Brightness and contrast were adjusted over the entire image and applied equally to control images from transgene negative samples for figure display. All image processing and statistical analysis of colocalization was preformed using the JACoP software in FIJI and described in detail in Materials and Methods. Statistical $t$ tests were performed in GraphPad Prism, version 7.0, and a significance criterion of $p<0.05$ was adopted. All other graphs and statistics [including mean, SEM, and $\mathrm{Cl}_{(0.95)}$ ] were also generated using GraphPad Prism.

\section{Results}

\section{Global and regional expression pattern of tPA in the adult murine brain}

Plat $\beta$ GAL reporter mice were used to characterize the global expression pattern of tPA in the adult murine brain. Serial coronal sections $(50 \mu \mathrm{m})$ from heterozygous Plat $\beta$ GAL mice were stained for $\beta$-Gal to assess regional patterning of somatic tPA expression. Prominent staining is present in layers 2-6 of the cortex (Fig. $1 A-F$ ), with an especially strong $\beta$-Gal signal highlighting the compact granule cell layer of the dentate gyrus and the pyramidal cell layer of the dorsal hippocampal CA3 subfield (Fig. $1 D$ ). Although less concentrated, the pyramidal cell layer of the CA1 and CA2 subfields in the dorsal hippocampus also demonstrates tPA $/ \beta$-Gal expression (Fig. $2 A$ ). In addition, $\beta$-Gal staining is apparent in blood vessels throughout the adult murine brain, as illustrated in the hippocampal formation (Fig. 2A, filled arrows). More diffuse reporter gene expression is present in subcortical regions, like the medial (Fig. 1B) and lateral (Fig. 1C) septal nuclei, the bed nucleus of the stria terminalis (Fig. $1 C$ ), the thalamus and hypothalamus (Fig. 1D,E), caudate/putamen (Fig. 1D), and the basolateral and centromedial nuclei of the amygdala (Fig. $1 D$ ), while intense $\beta$-Gal staining populates the molecular and granular layers of the cerebellum (Fig. 1G,H). There is also noticeable $\beta$-Gal staining in the midbrain, pons, and medulla (Fig. 1E-H); specifically, there is a cluster of reporter gene expression in the interpeduncular nucleus (Fig. 1F). The interpeduncular nucleus is an integral group of cells involved in limbic midbrain circuitry and has been implicated in active avoidance behavior (Hammer and Klingberg, 1990). Interestingly, multiple groups have demonstrated a role for IPA in avoidance behavioral tasks (Huang et al., 1996; Calabresi et al., 2000; Pawlak et al., 2002), although interpeduncular tPA has never been explicitly examined. Also, in the pontine central gray (Fig. $1 G)$, there is a small area devoid of $\beta$-Gal staining that appears to correspond to the locus coeruleus, which is known for its high concentration of neuroserpin, the neuronal inhibitor of tPA (Krueger et al., 1997). The regional patterning of tPA in the Plat $\beta$ GAL mice is largely consistent with previous reports examining IPA expression using [ ${ }^{\mathrm{P} 32]-l a b e l e d ~ t P A}$ cRNA probes (Sappino et al., 1993) and transgenic mice with tPA promoter-directed expression of $\beta$-Gal (Carroll et al., 1994; Yu et al., 2001). However, some differences were observed, such as strong tPA expression in the CA3 subfield and blood vessels (Fig. 2A), suggesting that the earlier studies lacked either the resolution or specific regulatory elements important for regional and cell specific expression.

\section{Differential expression pattern between where tPA is synthesized and where it is trafficked in the dorsal hippocampus}

Immunohistochemical analysis of heterozygous Plat $\beta \mathrm{GAL}$ mice, which have one functional copy of the TPA gene and one copy of the LacZ gene, reveals tPA to have a differential expression pattern. Using an antibody directed against tPA, there is a distinct uncoupling between the sites of tPA synthesis and sites of IPA trafficking. This is most apparent in 

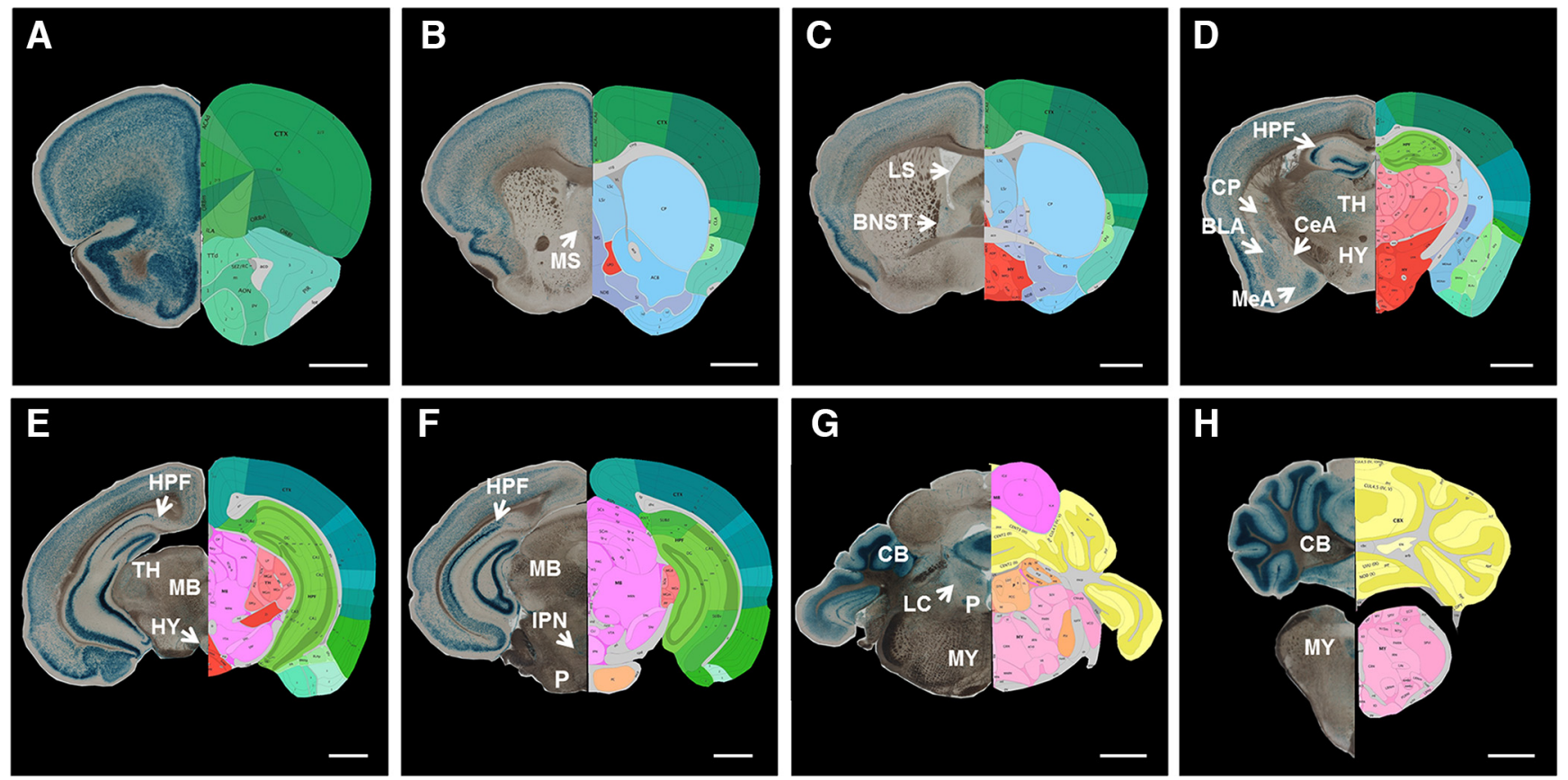

Figure 1. 5-Bromo-4-chloro-3-indolyl- $\beta$-D-galactoside analysis of tPA expression in Plat $\beta$ GAL reporter mice. Representative images $(10 \times)$ from a heterozygous Plat $\beta$ GAL reporter mouse (mice, $n=5)$ stained for $\beta$-Gal. Sections $(50 \mu \mathrm{m})$ were cut coronally starting from the frontal cortex around bregma +2.5 and progressing caudally to the cerebellum around bregma -8.0 . tPA $\beta$-Gal activity is strongly present in the cortex $(\boldsymbol{A}-\boldsymbol{F})$, in the granule and pyramidal cell layers of the hippocampus $(\boldsymbol{D}-\boldsymbol{F})$, and in the molecular and granular layers of the cerebellum $(\boldsymbol{G}, \boldsymbol{H})$. More diffuse tPA $\beta$-Gal staining is observable in subcortical regions, such as the medial $(\boldsymbol{B})$ and lateral septal nuclei $(\boldsymbol{C})$, the bed nucleus of the stria terminalis $(\boldsymbol{C})$, caudate/putamen $(\boldsymbol{D})$, the basolateral and centromedial nuclei of the amygdala $(\boldsymbol{D})$, and thalamus and hypothalamus $(\boldsymbol{D}, \boldsymbol{E})$. The locus coeruleus, where neuroserpin, the neuronal inhibitor of tPA is highly concentrated, is largely devoid of tPA $\beta$-Gal staining $(\boldsymbol{G})$. There are also distinct $\beta$-Gal clusters in midbrain, pontine, and medulla structures $(\boldsymbol{F}, \boldsymbol{G})$, such as the interpeduncular nucleus $(\boldsymbol{F})$. Coronal reference atlas images (were taken from the Allen Developing Mouse Brain Atlas; http://mouse.brain-map.org/static/atlas). From $\boldsymbol{A}-\boldsymbol{H}$, the following thumbnails were used: $32,47,53,71,82,89$, 109, and 123, respectively. MS, medial septal nuclei; LS, lateral septal nuclei; BNST, bed nucleus of the stria terminalis; HPF, hippocampal formation; TH, thalamus; $\mathrm{CP}$, caudate/putamen; BLA, basolateral nucleus of the amygdala; CeA, central nucleus of the amygdala; MeA, medial nucleus of the amygdala; HY, hypothalamus; MB, midbrain; IPN, interpeduncular nucleus; P, pons; LC, locus coeruleus; CB, cerebellum; MY, medulla. Scale bars: $1 \mathrm{~mm}$. Reference atlas images credit: Allen Institute.
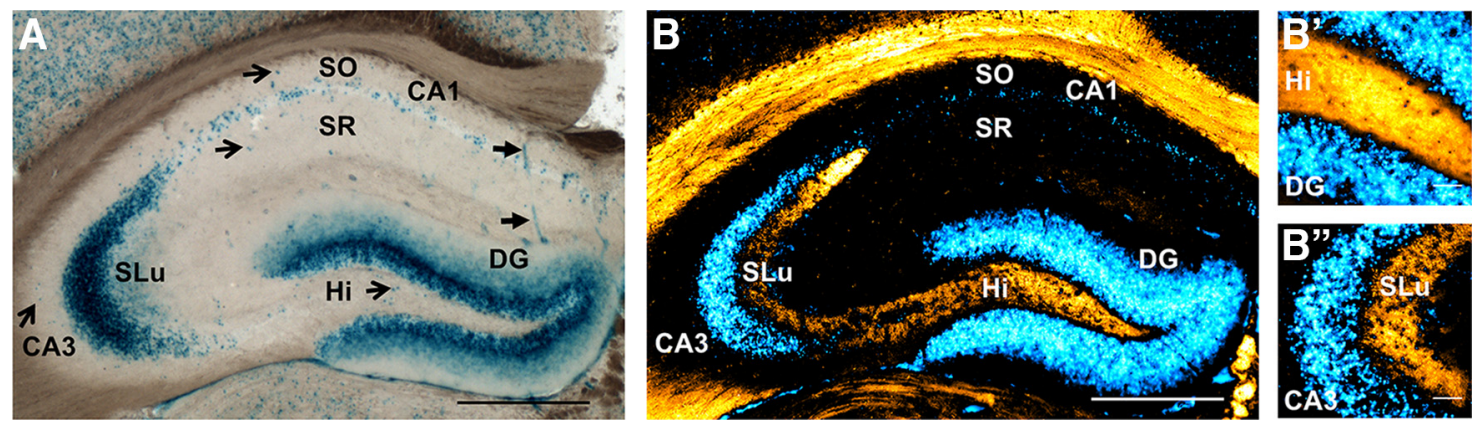

Figure 2. Immunohistochemical analysis of tPA protein expression in the hippocampus of Plat $\beta$ GAL reporter mice reveals a differential expression pattern between the sites of tPA synthesis and tPA trafficking. $\boldsymbol{A}$, Representative image (10X) of a 50- $\mu$ m hippocampal section from a heterozygous Plat $\beta$ GAL reporter mouse (mice, $n=5$ ). tPA is shown to be strongly expressed in the granule cell layer of the dentate gyrus and the pyramidal cell layer of hippocampal regions CA1-CA3. There are also scattered $\beta$-Gal puncta (arrows) in the hilus, SR, and SO; $\beta$-Gal staining is also present in blood vessels in the hippocampus (filled arrows). $\boldsymbol{B}$, Immunohistochemical analysis of a representative image $(10 \times)$ from a 50- $\mu \mathrm{m}$ hippocampal section from a heterozygous Plat $\beta$ GAL reporter mouse (mice, $n=5$ ) using antibodies directed against murine tPA (orange). In contrast to the $\beta$-Gal stain (cyan), tPA is not expressed in the cell body layers, but in the mossy fiber axons of dentate granule cells in the hilus and stratum lucidum lamina ( $\boldsymbol{B}^{\prime}$, $\left.B^{\prime \prime}, 40 \times\right)$. To visualize the colored $\beta$-Gal stain in the immunofluorescent image captured showing tPA-immunoreactivity, a negative of the fluorescent image was generated and pseudo-colored cyan. SLu, stratum lucidum; Hi, hilus; DG, dentate gyrus. Scale bars: 500 $\mu \mathrm{m}(\boldsymbol{A}, \boldsymbol{B})$ and $50 \mu \mathrm{m}\left(\boldsymbol{B}^{\prime}, \boldsymbol{B}^{\prime \prime}\right)$. 
the dorsal hippocampus where the granule cell layer of the dentate gyrus is brightly positive for $\beta$-Gal, but devoid of tPA-immunoreactivity (Fig. $2 A, B, B^{\prime}$ ). Conversely, the mossy fiber axonal tracts of the granule cells that project into the hilus (Fig. 2B') and traverse along stratum lucidum (Fig. 2B') are strongly immunoreactive against anti-tPA antibodies. Although strongly expressing $\beta$-Gal, no tPA-immunoreactivity is detectable in the granule cell layer or CA3 pyramidal layer (Fig. 2B-B').

Given the disparate expression profiles of where tPA is synthesized and where it is trafficked, a more targeted strategy for visualizing tPA is needed. To achieve this, BAC technology was used to generate transgenic fusion reporter mice that have a fluorescent cerulean protein tagged to the C-terminus of tPA (Fig. $3 A$ ). Compared to a reporter gene approach, the tPA-Cer fusion reporter approach facilitates a more precise analysis of the regional, cellular, and subcellular expression pattern of tPA in the adult murine brain. And, it can lead to greater functional insights about the dynamic nature of IPA in the brain, including cellular packaging and transport, cellular communication, and regional connectivity.

\section{Global tPA protein expression profile in PPA $^{\text {BAC }}$ Cerulean transgenic mice}

Before a detailed characterization of tPA localization in tPA ${ }^{\mathrm{BAC}}$-Cer mice, global tPA protein expression levels were measured. Brains from transgene-positive and transgene-negative adult $\mathrm{TPA}^{\mathrm{BAC}}$-Cer mice (mice, $n=$ 6-7) were harvested and homogenized for total and active protein levels using a bead-based Luminex assay (Fig. $3 B$ ) and ELISA (Fig. 3 C). tPA $^{\mathrm{BAC}}$-Cer mice were found to have an approximate 5-6 fold change in total tPA levels from transgene negative mice (Fig. $3 B$ ), and an approximate 6 fold change in active tPA levels from transgene negative mice (Fig. $3 C$ ). No statistical difference in total or active tPA was noted between the two transgenic lines. To more specifically discriminate between endogenous tPA protein and that which is from the BAC, whole-brain homogenates from transgenic TPA $^{\mathrm{BAC}}$-Cer mice (lines 863 and 876) and their respective transgene negative littermate controls were run on a zymography gel (Fig. 3D). Transgene-positive $\mathrm{TPA}^{\mathrm{BAC}}$-Cer mice showed enzymatic activity from both endogenous tPA $(\sim 60 \mathrm{kDa})$ and the tPA-Cer protein $(\sim 75 \mathrm{kDa})$. Samples from transgene negative mice did not display the higher molecular weight band that is indicative of tPA protein with the added cerulean fluorescent protein.

\section{tPA-Cer fusion protein is prominently expressed in limbic structures and blood vessels in the adult murine brain}

In a global survey of tPA-Cer fluorescence in $\mathrm{TPA}^{\mathrm{BAC}}$ Cer transgenic mice, tPA-Cer puncta appear to be primarily restricted to two pools: nerve fibers (Fig. $4 A-G, I-M$ ) and vascular endothelial cells (Fig. $4 N$ ). No observable cerulean fluorescence was detected in transgene negative littermate controls (Fig. $5 A-F, H$ ). In the brain parenchyma, faint tPA-Cer cell bodies are noticeable in the piriform and entorhinal cortex (Fig. 4A-E), while more predominant and intense tPA-Cer fluorescence is seen in
A

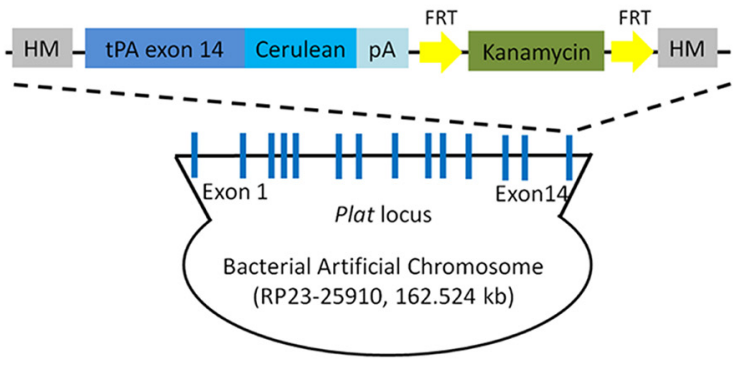

B Total tPA Protein

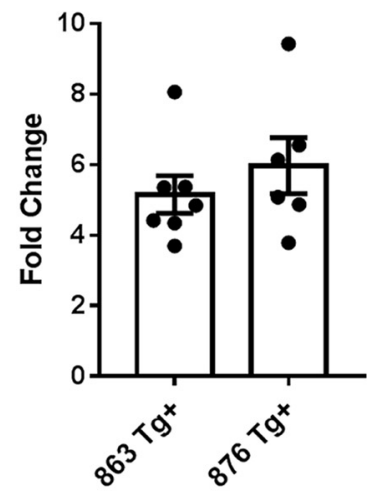

C Active tPA Protein

D

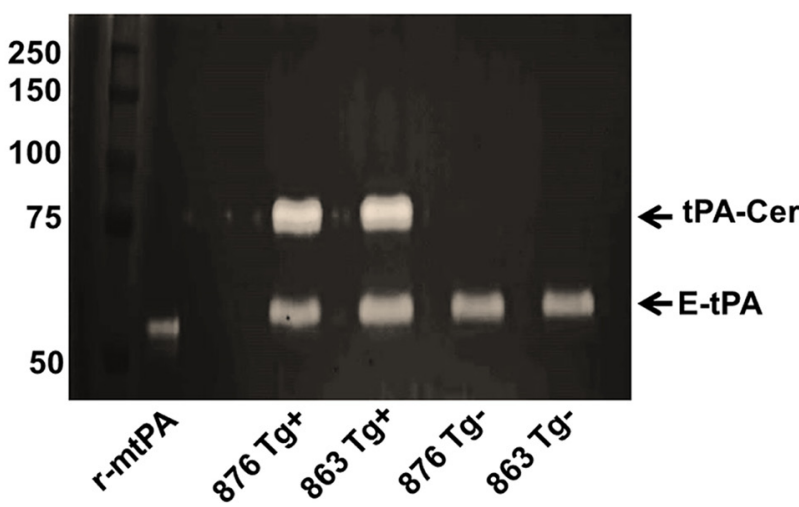

Figure 3. Generation and global tPA protein characterization of $t_{P A}{ }^{B A C}$-Cerulean transgenic mice. $\boldsymbol{A}$, Founder lines for $\mathrm{TPA}^{\mathrm{BAC}}$ Cer transgenic mice (863 and 876) were generated using BAC technology. To generate tPA ${ }^{\mathrm{BAC}}$-Cer transgenic mice, a kanamycin-resistance recombineering cassette containing a cerulean fluorescent gene fused to the C-terminus of exon 14 of the tPA gene was recombineered into a BAC. The tPA-Cer fusion gene is under control of endogenous regulatory elements contained in the Plat locus. $\boldsymbol{B}-\boldsymbol{D}$, Protein expression profile of $\mathrm{tPA}^{\mathrm{BAC}}$ Cer transgenic mice. Brains from transgene-positive and transgene-negative adult $\mathrm{tPA}^{\mathrm{BAC}}-\mathrm{Cer}$ mice were harvested and homogenized for total and active protein quantification using a bead-based Luminex assay $(\boldsymbol{B})$ and ELISA $(\boldsymbol{C})$. Data are presented as the mean \pm SEM fold change from tPA protein levels in transgene negative littermate controls (mice $n$ $=6-7$ ). No statistical difference was noted in total and active tPA protein levels between line 863 and 876 . D. Zymographic analysis of whole-brain homogenates from tPA ${ }^{\mathrm{BAC}}$-Cer transgene positive and negative mice (lines 863 and 876 ) visually 


\section{continued}

delineates endogenous tPA (lower molecular weight bands, E-tPA) and the tPA-Cer from the BAC (higher molecular weight bands, tPA-Cer). Not only is there increased levels of tPA protein in both TPA $^{\mathrm{BAC}}$-Cer transgenic lines, but the tPA-Cer protein is proteolytically active. FRT, flippase recognition target; HM, homology arms; r-mtPA, recombinant-murine tPA; E-tPA, endogenous-tPA. nerve fibers in hippocampal and subcortical regions of the brain. Juxtaposed to the somatic neuronal marker NeuN, tPA-Cer fluorescence is clearly not localized to the cell body; rather, it appears to be expressed in nerve fibers emanating or innervating brain structures associated with the limbic system, including the medial and lateral septal nuclei (Fig. 4B), the bed nucleus of the stria terminalis (Fig. $4 C, I$ ), the paraventricular nucleus of the thalamus (Fig.
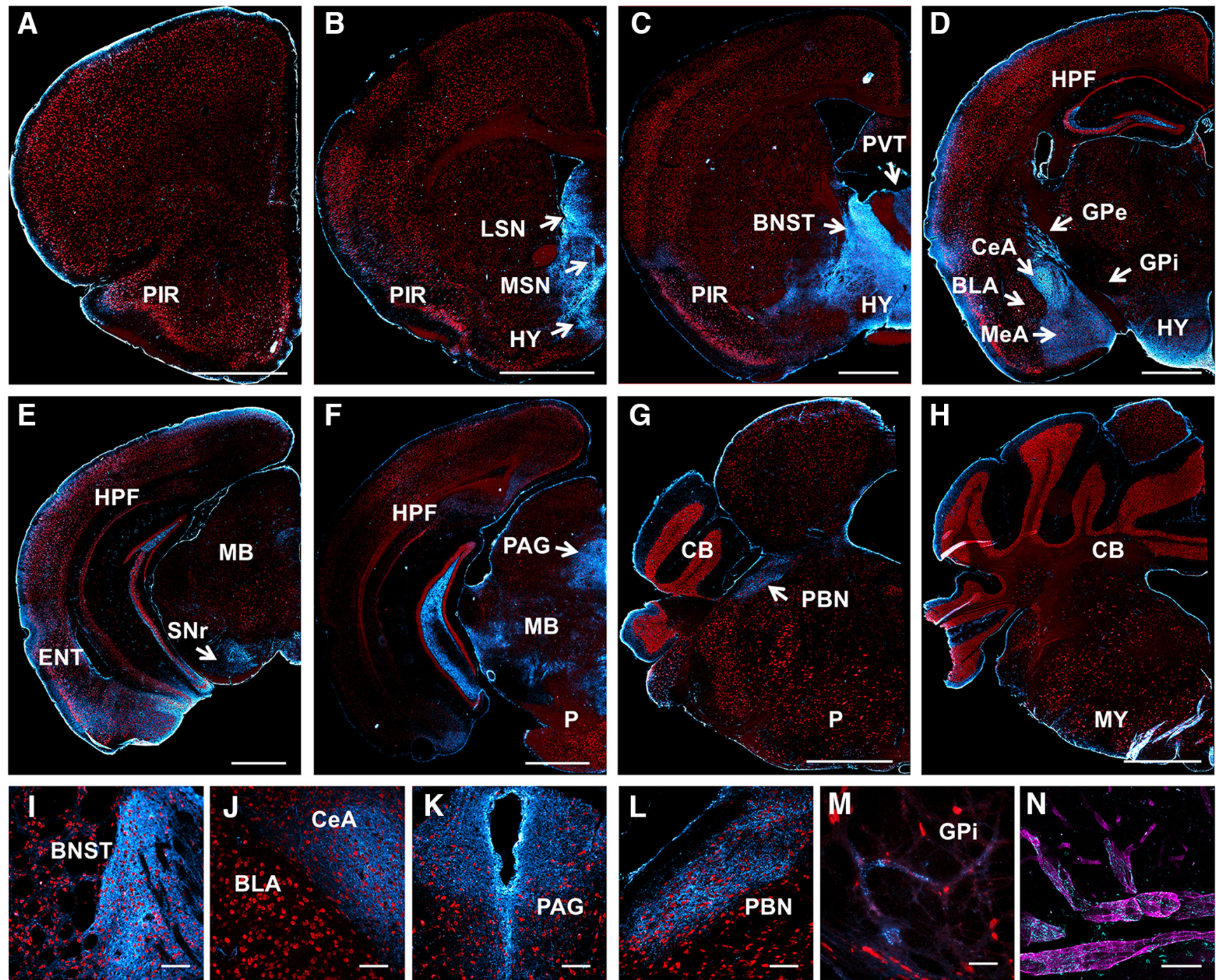

Figure 4. tPA-Cer fusion protein is prominently expressed in limbic structures and blood vessels in the adult murine brain. Images shown are representative of stitched serial coronal sections from tPA ${ }^{\text {BAC }}$-Cer transgenic mice $(n=3)$ captured on a widefield microscope $(\boldsymbol{A}-\boldsymbol{H}, 10 \times ; \boldsymbol{I} \boldsymbol{L}, 20 \times ; \boldsymbol{M}, 40 \times)$ or confocal microscope $(\boldsymbol{N}, 63 \times)$. Cryosections stained for the neuronal marker NeuN (red) clearly distinguishes the faint tPA-Cer (cyan) cells bodies observed in the piriform $(\boldsymbol{A}-\boldsymbol{D})$ and entorhinal cortex (E), and the tPA-Cer fluorescent nerve fibers found in the medial and lateral septal nuclei $(\boldsymbol{B})$, the bed nucleus of the stria terminals $(\boldsymbol{C}, \boldsymbol{I})$, the paraventricular nucleus of the thalamus $(\boldsymbol{C})$ and hypothalamus $(\boldsymbol{D})$, the central $(\boldsymbol{D}, \boldsymbol{J})$ and medial $(\boldsymbol{D})$ nuclei of the amygdala, the external globus pallidus $(\boldsymbol{D})$ and internal globus pallidus $(\boldsymbol{M})$ of the basal ganglia, the substantia nigra pars reticulata, $(\boldsymbol{E})$, the periaqueductal gray $(\boldsymbol{F}, \boldsymbol{K})$, and the parabrachial nucleus $(\boldsymbol{G}, \boldsymbol{L})$. tPA is also robustly expressed in the hilus and mossy fiber pathway of the hippocampus $(\boldsymbol{D}-\boldsymbol{F})$. $\boldsymbol{G}, \boldsymbol{H}$, In contrast to the Plat $\beta$ GAL reporter mice, tPA expression is not observable in the cerebellum. $\boldsymbol{N}$, Brightly positive tPA-Cer puncta are noticeable throughout all brain regions in blood vessels using the endothelial cell marker, CD31 (magenta). PIR, piriform cortex; ENT, entorhinal cortex; LS, lateral septal nuclei; MS, medial septal nuclei; BNST, bed nucleus of the stria terminalis; PVT, paraventricular nucleus of the thalamus; HY, hypothalamus; HPF, hippocampal formation; CeA, central nucleus of the amygdala; MeA, medial nucleus of the amygdala; BLA, basolateral nucleus of the amygdala; PAG, periaqueductal gray; PBN, parabrachial nucleus; GPe, globus pallidus external segment; GPi, globus pallidus internal segment; SNr, substantia nigra pars reticulata; $M B$, midbrain; $P$, pons; CB, cerebellum; MY, medulla. Scale bars: $1 \mathrm{~mm}(\boldsymbol{A}-\boldsymbol{H}), 100 \mu \mathrm{m}(\boldsymbol{I}-\boldsymbol{M})$, and $50 \mu \mathrm{m}(\boldsymbol{K}, \boldsymbol{N})$. 

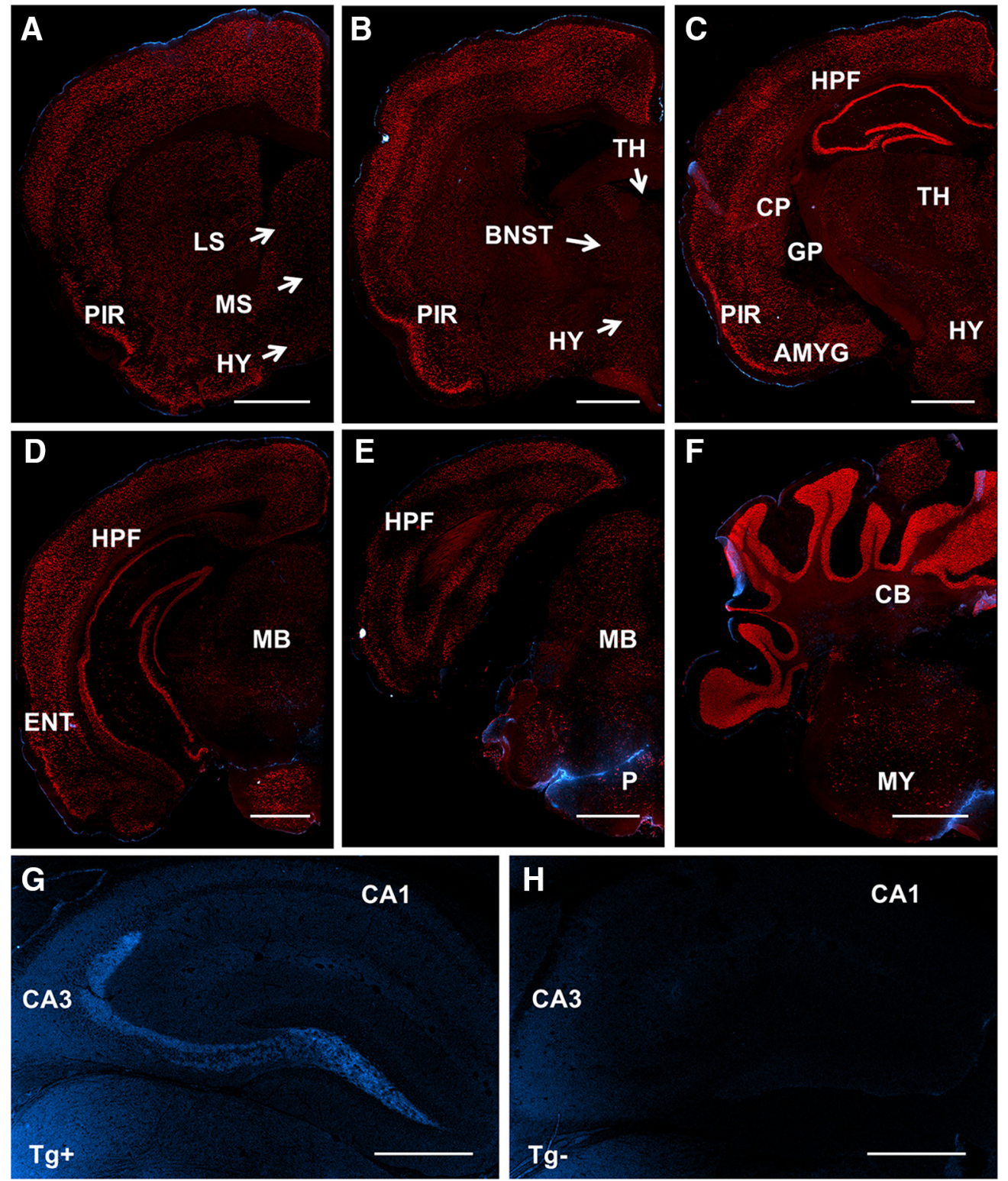

Figure 5. tPA-Cer fluorescence is not observed in $\mathrm{PPA}^{\mathrm{BAC}}-\mathrm{Cer}$ transgene negative littermate controls. $\boldsymbol{A}-\boldsymbol{D}$, Images shown are representative of stitched serial coronal sections from $\mathrm{TPA}^{\mathrm{BAC}}-\mathrm{Cer}$ transgene negative littermate mice $(n=2)$ captured on a widefield microscope $(10 \times)$. Cyrosections $(14 \mu \mathrm{m})$ stained for the neuronal marker NeuN (red) show no cerulean fluorescence in cell bodies in the piriform $(\boldsymbol{A}-\boldsymbol{C})$ or entorhinal cortex $(\boldsymbol{D})$. Cerulean fluorescence is also not observable in the medial and lateral septal nuclei $(\boldsymbol{B})$, the bed nucleus of the stria terminals $(\boldsymbol{B})$, the amygdala $(\boldsymbol{C})$, globus pallidus $(\boldsymbol{C})$, or the thalamus and hypothalamus $(\boldsymbol{B}, \boldsymbol{C})$. Midbrain and pontine brain structures are devoid of any cerulean fluorescence $(\boldsymbol{D}, \boldsymbol{E})$, as are the medulla and cerebellum $(\boldsymbol{F})$. $\boldsymbol{G}, \boldsymbol{H}$, Representative images from widefield microscopy $(4 \times)$ of the hippocampus from a tPA ${ }^{B A C}$-Cer transgene-positive $(T g+)$ mouse and its transgenenegative (Tg-) littermate. Cerulean fluorescence is clearly observable in the mossy fiber pathway of a tPA ${ }^{B A C}$-Cer transgene-positive mouse, but completely absent in the transgene-negative control. Cerulean fluorescent artifacts from edge effects or folds are apparent in panels $\boldsymbol{C}, \boldsymbol{E}, \boldsymbol{F}$. PIR, piriform cortex; ENT, entorhinal cortex; LS, lateral septal nuclei; MS, medial septal nuclei; BNST, bed nucleus of the stria terminalis; TH, thalamus; HPF, hippocampal formation; AMYG, amygdala; HTH, hypothalamus; CP, caudate/ putament; GP, globus pallidus; MB, midbrain; P, pons; CB, cerebellum; MY, medulla. Scale bars: $1 \mathrm{~mm}(\boldsymbol{A}-\boldsymbol{F})$ and $500 \mu \mathrm{m}(\boldsymbol{G}, \boldsymbol{H})$.

$4 C$ ), hypothalamus (Fig. $4 C, D$ ), the mossy fiber pathway of the hippocampus (Figs. 4D-F, 5G), the centromedial nucleus of the amygdala (Fig. $4 D, J$ ), the external globus pallidus (GPe) and internal globus pallidus (GPi) nuclei of the basal ganglia (Fig. 4D,M), the substantia nigra pars reticulata (SNr; Fig. 4E), the periaqueductal gray (Fig. $4 F, K)$, and the parabrachical nucleus (Fig. $4 G, L$ ).
In situ zymography previously demonstrated tPA activity in the mossy fiber pathway and hypothalamus (Sappino et al., 1993), the bed nucleus stria terminalis (Matys et al., 2004), and the centromedial, but not basolateral, nucleus of the amygdala (Pawlak et al., 2003). To our knowledge, however, we are the first to report on tPA expression in the paraventricular nucleus of the thalamus, 
the periaqueductal gray, and the parabrachial nucleus. These regions, in addition to the bed nucleus stria terminalis and the hypothalamus, are connected via afferent and/or efferent projections to the centromedial amygdalar nucleus (Janak and Tye, 2015; Penzo et al., 2015; Tasan et al., 2016; Babaev et al., 2018). Neurons in the basolateral nucleus also send projections to the centromedial nucleus. And, while $\beta$-Gal expression was detected in both the basolateral and centromedial nuclei, given the complex circuitry of the amygdala, it is unclear if the tPA-Cer fluorescence in the centromedial nucleus is trafficked tPA from basolateral nerve projections or trafficked tPA in afferent/efferent nerve fibers to/from other brain regions.

We also report, for the first time, on tPA expression in the GPe and GPi nuclei of the basal ganglia. Indeed, the differential expression of somatic tPA $/ \beta$-Gal and trafficked tPA-Cer is appreciable when comparing IPA expression in the Plat $\beta \mathrm{GAL}$ (Fig. $1 D$ ) and $\mathrm{TPA}^{\mathrm{BAC}}$-Cer (Fig. $4 D$ ) transgenic mice. While $\beta$-Gal staining is present in the caudate/putamen nucleus, it is devoid in both the GPe and GPi nuclei in the Plat $\beta$ GAL reporter mice (Fig. 1D). In contrast, tPA-Cer fluorescence is absent in the caudate/ putamen, but present in the GPe, GPi, and SNr (Fig. 4D,E). The GPi and SNr are equivalent anatomic structures, both embryologically and functionally (Purves et al., 2001), as they are the output nuclei of the basal ganglia. Given that tPA-Cer, but not $\beta$-Gal, is present in the GPe, it is likely that the observed tPA-Cer is part of the direct loop through the basal ganglia. The circuitry of the direct loop involves GABAergic neurons that project from caudate/ putamen through the GPe to the GPi or GABAergic neurons from caudate/putamen that travel through the strionigral fibers to SNr (Purves et al., 2001; Gilman and Newman, 2002). In turn, both the GPi and SNr send GABAergic projections to the thalamus. The direct loop is known to increase thalamocortical excitation, and it is important for the selection of desired behaviors (Purves et al., 2001; Gilman and Newman, 2002). Together, the high expression of tPA-Cer fluorescence in cell bodies and nerve fibers in limbic structures, especially amygdalar-associated brain regions, strongly support a role for tPA in affective, motivational, and anxiety-like behavior (Pawlak et al., 2002, 2003; Matys et al., 2004). And, while tPA has yet to be studied in the basal ganglia, more recent evidence has suggested that, functionally, the basal ganglia are more than an "organ of habit" in the brain, as it plays a role in perception, cognition, and emotional behaviors (Jahanshahi et al., 2015).

\section{tPA-Cer puncta are localized to large MFBs in the stratum lucidum CA3 subregion of the hippocampus}

Our previous results established that tPA-Cer fluorescence is highly enriched in the mossy fiber pathway (Figs. $4 D, 5 G$ ). These findings are consistent with immunohistochemical analysis and in situ zymography which also report high levels of tPA localization and proteolytic activity in the mossy fiber pathway (Sappino et al., 1993; Salles and Strickland, 2002; Louessard et al., 2016). As mossy fiber axons are known to have morphologically and functionally distinct presynaptic terminals we leveraged the use of the $\mathrm{TPA}^{\mathrm{BAC}}$-Cer mice, combined with highresolution confocal imaging, to establish tPA's subcellular distribution in the hippocampus. Confocal z-stacks were captured of both tPA-Cer and putative colocalization markers. Dorsal hippocampal sections from tPA ${ }^{B^{A C}}-C e r$ mice were first probed for zinc transporter-3 (ZnT3), which is the protein correlate underlying the Timm's histochemical stain to visualize the mossy fiber pathway (Frotscher et al., 1994). ZnT3 was used based on previous electron microscopy immunocytochemistry of ZnT3 in the murine brain which revealed the exclusive localization of ZnT3 to large MFBs (Wenzel et al., 1997). An analysis of orthogonal $Y Z$ and $X Z$ sections from a 5- $\mu \mathrm{m}$ z-stack $(\Delta z=0.5$ $\mu \mathrm{m})$ suggests that tPA-Cer puncta colocalize with $\mathrm{ZnT3}$ (Fig. 6A). Further, 3D projection confirms that tPA-Cer puncta reside in ZnT3-positive MFBs (Fig. 6A'). As shown in Figure $6 D, E$, quantification of colocalization between tPA and ZnT3 from 5- $\mu \mathrm{m}$ concatenated image stacks (mice, $n=10$ ), shows that tPA-Cer has a high degree of overlap with ZnT3 (M1 coefficient: 0.704 and 0.649 for lines 863 and 876 , respectively; Costes probability $p$ value $\geq 95 \%$ ). There was no observable detection of cerulean fluorescence in transgene negative littermate controls (Fig. 5H). Conversely, ZnT3 shows only partial overlap with tPA-Cer (M2 coefficient: 0.426 and 0.352 for lines 863 and 876 , respectively). The lack of a one-to-one relationship between the M1 and M2 coefficients is possibly due to the zinc transporter being a synaptic, not dense core, vesicle marker. Although dense core vesicles are sporadically found in MFBs (Wenzel et al., 1997; Rollenhagen et al., 2007), synaptic vesicles are much more abundant. ZnT3 staining, therefore, likely illuminates a larger area of the MFB, while the tPA-Cer signal, presumably in dense core vesicles, appears more punctate (Silverman et al., 2005; Lochner et al., 2008; Scalettar, et al., 2012). Lastly, these data indicate that while the vast majority of tPA is localized to giant MFBs there is also a population that occupies another locale.

As astrocytes are known to wrap fine processes around MFBs (Rollenhagen and Lubke, 2010) and as tPA has been shown to be taken-up by astrocytes (Cassé et al., 2012), $\mathrm{tPA}^{\mathrm{BAC}}$-Cer hippocampal sections were stained for the astrocytic glutamate transporter EAAT2 (excitatory amino acid transporter 2). While a strong visual colocalization was difficult to ascertain from orthogonal $Y Z$ and $\mathrm{XZ}$ slices (Fig. 6B) and 3D projections (Fig. 6B'), image quantification (Fig. $6 D, E$ ) did demonstrate lower levels of colocalization (M1 coefficient: 0.183 and 0.198 for lines 863 and 876 , respectively; Costes probability $p$ value $\geq$ $95 \%)$. To further validate our results, $\mathrm{APA}^{\mathrm{BAC}}$-Cer sections were stained for the dendritic marker MAP2 (microtubule associated protein 2) as a negative control. In stratum lucidum, MAP2 detects the dendritic thorny excrescences of CA3 pyramidal neurons which are the postsynaptic partner to the MFBs. As predicated, orthogonal $Y Z$ and XZ slices of tPA-Cer and MAP2 showed no visual overlap (Fig. 6C) and a 3D projection (Fig. 6C') showed that tPA-Cer puncta encapsulate the MAP2-positive dendritic thorny excrescences. Moreover, when quantified (Fig. 

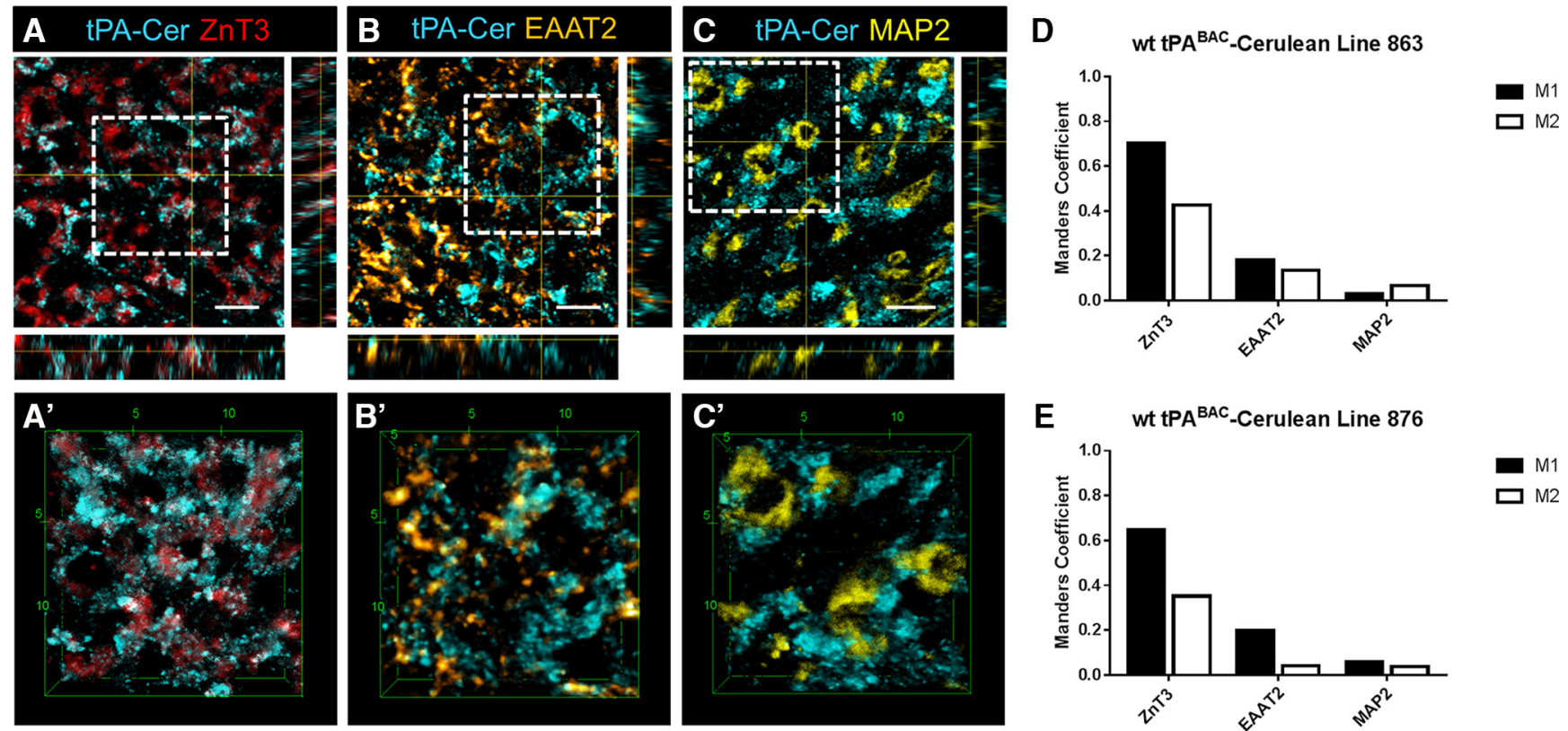

E

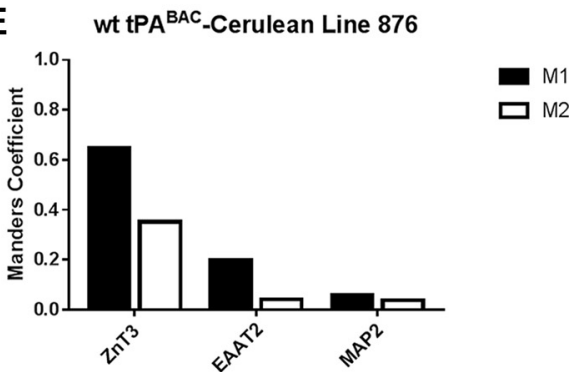

Figure 6. tPA-Cer is localized to large MFBs and astrocytes in the CA3 stratum lucidum lamina of the hippocampus. Subcellular colocalization of tPA in stratum lucidum of the hippocampus was investigated using high-resolution confocal microscopy. Images $(63 \times)$ are representative regions of interest from the stratum lucidum lamina of PAA $^{\mathrm{BAC}}-$ Cer transgenic mice and are presented as 5 - $\mu \mathrm{m}$ Z-stacks $(\Delta \mathrm{Z}=0.5 \mu \mathrm{m})$ visualized in orthogonal $Y Z$ and $X Z$ slices $(\boldsymbol{A}-\boldsymbol{C})$ and magnified 3D maximum intensity projections $\left(\boldsymbol{A}^{\prime}-\boldsymbol{C}^{\prime}\right)$, for each of the respective colocalization markers. For quantification of colocalization using the Manders coefficient $(\boldsymbol{D}$, $\boldsymbol{E})$ entire images were concatenated from $5-\mu \mathrm{m} z$-stacks $(512 \times 512$ pixels; $\Delta z=0.5 \mu \mathrm{m})$ that were independently acquired two to four times (ZnT3: mice $n=10$, lines 863 and 876; EAAT2: mice $n=6-8$, lines 863 and 876, respectively; MAP2: mice $n=4$, lines 863 and 876). tPA-Cer puncta was found to colocalize with the zinc transporter-3 (ZnT3; red), which has previously been observed exclusively in MFBs, as indicated visually by the white overlay in the orthogonal sections and 3D max projection (Manders M1: 0.704 and 0.649 for lines 863 and 876, respectively; Costes probability $p$ value $\geq 95 \% ; \boldsymbol{D}, \boldsymbol{E}$ ). Partial colocalization was weakly observed in astrocytes visualized with the astrocytic glutamate transporter EAAT2 (orange; $\boldsymbol{B}, \boldsymbol{B}^{\prime}$ ), which is in agreement with the lower quantified colocalization coefficient (Manders M1: 0.183 and 0.198 for lines 863 and 876 , respectively; Costes probability $p$ value $\geq 95 \% ; \boldsymbol{D}, \boldsymbol{E}$ ). To confirm the presynaptic localization of tPA to MFBs, sections were also stained for the dendritic marker MAP2, which detects the dendritic thorny excrescences of CA3 pyramidal neurons that MFBs encase. Orthogonal YZ and XZ slices and 3D max projections of tPA-Cer and MAP2 (yellow; $\boldsymbol{C}, \boldsymbol{C}^{\prime}$ ) showed no colocalization (Manders M1: 0.032 and 0.060 for lines 863 and 876 , respectively; Costes probability $p$ value $=0.0 \% ; \boldsymbol{D}, \boldsymbol{E})$. ZnT3, zinc-transporter 3; EAAT2, excitatory amino acid transporter 2; MAP2, microtubule associated protein 2. Scale bars: $5 \mu \mathrm{m}(\boldsymbol{A}-\boldsymbol{C})$ and the units on the scale boxes are given in $\mu \mathrm{m}\left(\boldsymbol{A}^{\prime}-\boldsymbol{C}^{\prime}\right)$.

$6 D, E)$, no colocalization was found (M1 coefficient: 0.032 and 0.060 for lines 863 and 876 , respectively; Costes probability $p$ value $=0 \%$ ).

\section{tPA is expressed in a subset of SST-positive inhibitory interneurons in SO/alveus of CA1 and CA3 hippocampal subfields}

The presence of sporadic $\beta$-Gal puncta in SO, SR, and the hilus (Fig. $2 A$ ) of the hippocampus in Plat $\beta$ GAL reporter mice suggested that other cell types, in addition to the granule and pyramidal cells, express tPA. In an effort to visualize and identify these cells in the $\mathrm{TPA}^{\mathrm{BAC}}-\mathrm{Cer}$ transgenic mice, the cerulean signal was magnified using a GFP antibody in conjunction with tyramide signal amplification. With amplification, tPA-Cer-positive cell bodies were revealed in the CA1 and CA3 hippocampal subfields of transgene positive mice (Fig. $7 A, E$ ). CA3 pyramidal cells became visible, but more strikingly were the sparsely-populated tPA-Cer-expressing cell somas in SO, $\mathrm{SP}$, and SR, although most were strongly localized to the SO/alveus lamina of the CA1 and CA3 subfields (Table 1). To quantify strata localization of tPA-Cer cell bodies, two to four hippocampal sections per mouse (mice, $n=8$ ) for each of the transgenic lines were analyzed. Our results show that for a hippocampal section there were, on average, $11.68 \pm 1.53(n=301$ cells $)$ and $10.90 \pm 2.06(n=$ 238 cells) tPA-Cer cells bodies in the CA1 SO/alveus region and $5.58 \pm 1.14(n=141$ cells) and $5.34 \pm 1.98(n$ $=115$ cells) tPA-Cer cell bodies in the CA3 SO/alveus region for lines 863 and 876 , respectively. Less frequently, on average, $3.32 \pm 1.15$ ( $n=78$ cells) and $2.28 \pm 1.06$ ( $n$ $=52$ cells) tPA-Cer cells bodies were found in SR and SP for lines 863 and 876, respectively. No statistical difference was noted between lines 863 and 876 .

The sporadic nature of tPA-Cer-positive cell bodies is consistent with that of GABAergic interneurons (Oliva et al., 2000). To test if tPA-Cer-positive cells are indeed GABAergic interneurons, various immuno-markers for $\mathrm{SO} /$ alveus-interneurons were used to neurochemically identify the subpopulation of tPA-Cer-positive cells in the hippocampus (Somogyi and Klausberger, 2005). tPA-Cerpositive cells were found to strongly coexpress the interneuronal marker SST in the SO/alveus lamina of hippocampal regions CA1 and CA3 (Table 1; Fig. 7). 

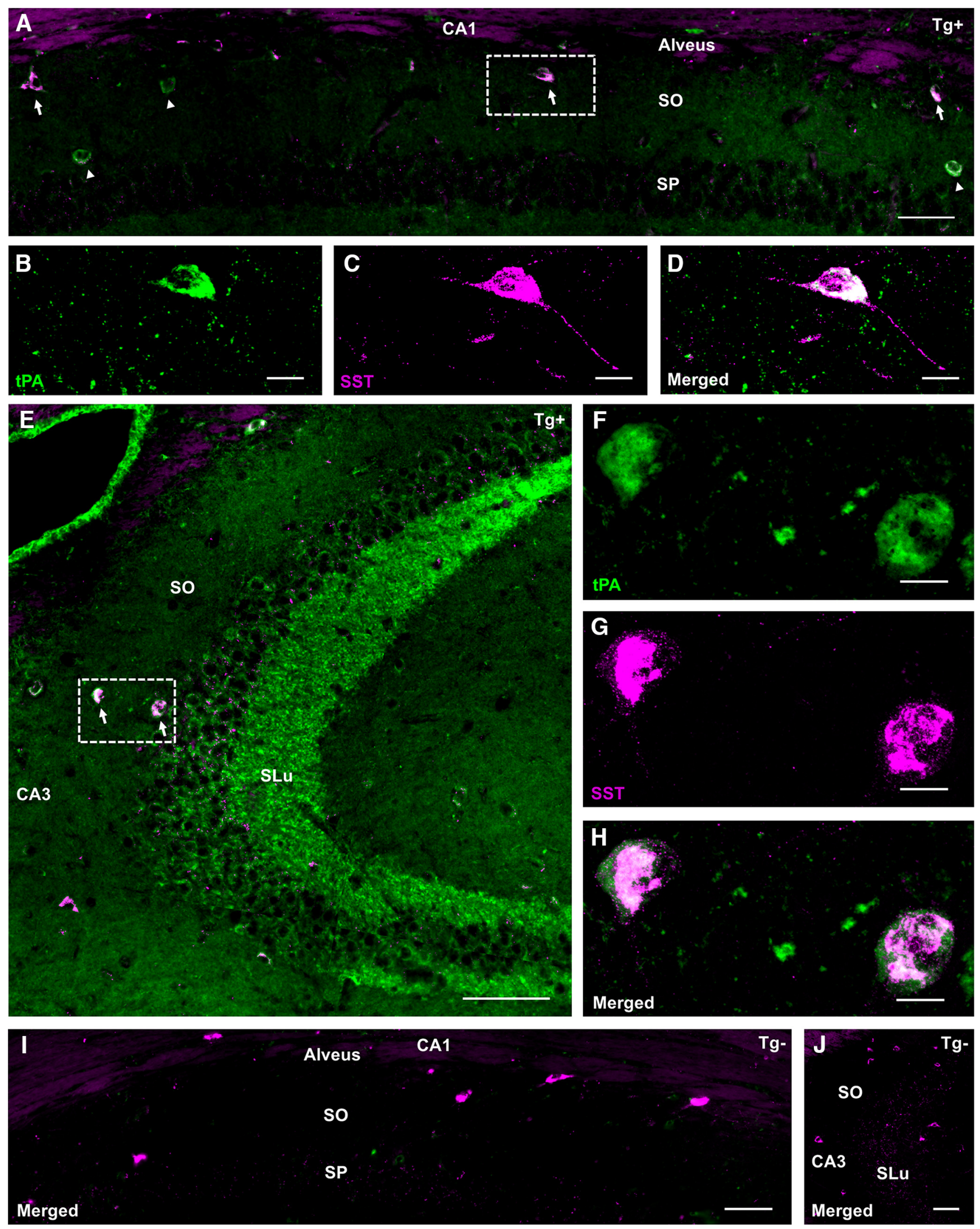

Figure 7. Amplification of tPA-Cer signal reveals a population of cells in SO/alveus of the hippocampal CA1 and CA3 regions that coexpress SST. Representative images of hippocampal CA1 $(\boldsymbol{A})$ and CA3 $(\boldsymbol{E})$ subfields from tPA $\mathrm{BAC}_{-}$-Cer transgenic mice $($mice, $n=$ 8) exemplifying the localization and distribution of tPA-Cer cell bodies (tPA; green) that coexpress the inhibitory interneuronal marker 
continued

SST (magenta). For localization and distribution statistics, see Table 1. With GFP tyramide signal amplification, somatic tPA is also detectable in the pyramidal cell layer of the CA3 subfield $(\boldsymbol{E})$, although it is still largely absent in the CA1 pyramidal cell layer $(\boldsymbol{A})$. Confocal $(63 \times)$ maximum intensity projections focused on a region of interest (dashed box) highlighting tPA-Cer-positive cells (tPA; green) that coexpress SST (magenta) from the CA1 $(\boldsymbol{B}-\boldsymbol{D})$ and CA3 $(\boldsymbol{F}-\boldsymbol{H})$ SO/alveus lamina. Unlike the punctate nature of tPA in axonal projections, tPA's somatic expression appears more diffuse. I, J, Immunostaining for SST and GFP with tyramide signal amplification in transgene negative controls only revealed SST-positive interneurons in the SO/alveus lamina of hippocampal CA1 (I) and CA3 (J). SLu, stratum lucidum. Scale bars: $50 \mu \mathrm{m}(\boldsymbol{A}), 10 \mu \mathrm{m}(\boldsymbol{C}, \boldsymbol{D}), 100 \mu \mathrm{m}(\boldsymbol{E}), 10 \mu \mathrm{m}(\boldsymbol{F}-\boldsymbol{H}), 50 \mu \mathrm{m}(\boldsymbol{I})$, and $100 \mu \mathrm{m}(\boldsymbol{J})$.

Widefield images of the hippocampus show prominent tPA expression in stratum luciudum (Fig. 7E), but also in SST-positive interneurons scattered throughout SO/alveus (Fig. 7A). Immunostaining for SST and GFP with tyramide signal amplification in transgene negative controls only revealed SST-positive interneurons (Fig. $7 I, J$ ). Confocal images from CA1 (Fig. 7B-D) and CA3 (Fig. $7 F-H)$ show tPA-Cer cells (green) that clearly overlap with SST-positive (magenta) interneurons. When quantified, for a given hippocampal section, on average $\sim 54.35 \pm$ $6.32 \%$ ( $n=520$ cells) and $58.90 \pm 6.74 \%(n=405$ cells $)$ of tPA-Cer cells were found to coexpress SST, while $53.89 \pm 8.82 \%(n=520$ cells $)$ and $44.66 \pm 9.45 \%(n=$ 540 cells) of SST-positive cells were found to coexpress tPA-Cer, for lines 863 and 876 , respectively. No statistical difference was noted between lines 863 and 876 .

Since O-LM interneurons, whose cell bodies reside in SO and send axonal projections to stratum lacunosummoleculare, are known to express SST (Fig. $8 A$ ), other neurochemical markers of O-LM interneurons were probed for to see whether tPA-Cer cells can be immunocytochemically classified as O-LM interneurons. tPA-Cer cells were found to coexpress the calcium-binding protein calbindin (Fig. $8 C$ ), which has previously been reported to comprise roughly $32 \%$ of SST/O-LM interneurons (Oliva et al., 2000); they were also found to coexpress the metabotropic glutamate receptor 1 (mGlur1a; Fig. 8B), which is highly expressed in SST/O-LM interneurons (Klausberger, et al., 2003; Somogyi and Klausberger, 2005; Sylwestrak and Ghosh, 2012). Interestingly, tPA mRNA polyadenylation and translation has previously been shown to be dependent on mGluR1 activation (Shin et al., 2004). To confirm the inhibitory nature of these cells, immunohistochemistry against GAD65 (glutamic acid decarboxylase 65) in TPA $^{B A C}$-Cer mice was performed (Fig. 8D). In agreement with the localization and cytochemical profile of SST/O-LM interneurons, tPA-Cer puncta were observed in structures reminiscent of axonal processes in SR (Fig. 8E). These data strongly suggest that at least a portion of tPA-Cer cells can be categorized as O-LM interneurons.

\section{Discussion}

In the present study, we have confirmed and extended our understanding of the expression of tPA in the adult murine brain. Using both a Plat $\beta G A L$ reporter mouse and a BAC transgenic mouse expressing a tPA-Cer fusion protein, we have provided a detailed characterization of the regional, cellular, and sub-cellular localization of tPA. While largely complimenting the expression pattern observed in transgenic mice that harbored a 9.5-kb segment of the human tPA promoter to drive expression of LacZ (Yu et al., 2001), Plat $\beta$ GAL reporter mice displayed differences that provide insight into the transcriptional regulation of tPA. In contrast to the Plat $\beta$ Gal reporter mice, in the human $9.5-\mathrm{kb}$ tPA ${ }^{\mathrm{LacZ}}$ reporter mouse, $\beta$-Gal staining was only weakly observed in the CA3 subfield, and there was no detection of $\beta$-Gal in blood vessels, a wellestablished site of tPA expression (Fredriksson et al., 2015; Louessard et al., 2016). In addition, Yu et al. (2001) observed high tPA/LacZ expression in the medial habenula, which was not the case for the Plat $\beta G A L$ reporter mice. These discrepancies suggest that regulatory elements important for the regional and cellular expression patterning of tPA are not encompassed in the 9.5-kb human promoter segment or that there are differences between the human and murine promoter sequences that do not completely recapitulate species specific expression of tPA.

When comparing the Plat $\beta G A L$ reporter mice and the $\mathrm{tPA}^{\mathrm{BAC}}$-Cer transgenic mice, there is a clear uncoupling between where tPA is synthesized and where it is trafficked, which is in agreement with previous in situ expression studies examining tPA mRNA and tPA-catalyzed proteolysis (Sappino et al., 1993). And, while the laminar, tri-synaptic circuitry of the hippocampus illustrates this

Table 1. Localization and coexpression of tPA-Cer-positive soma in hippocampus of tPA ${ }^{\mathrm{BAC}}$-Cer mice

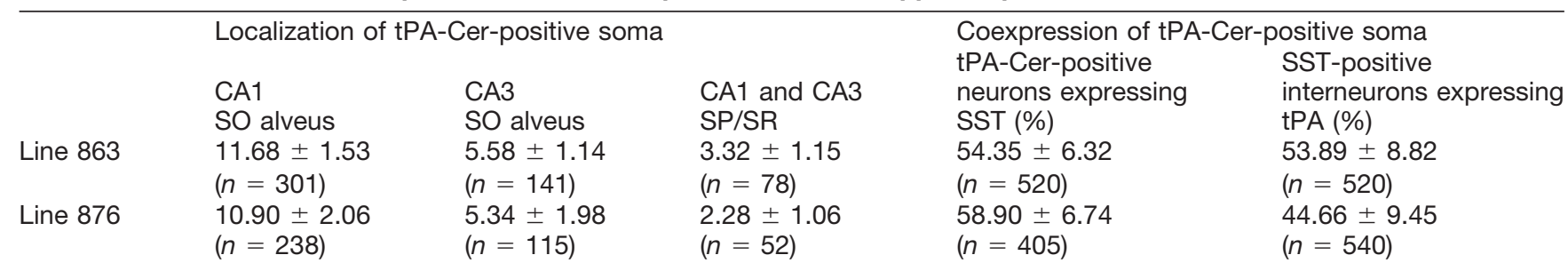

Results are presented as the mean $\pm \mathrm{Cl}_{(0.95)}$ for a given hippocampal section. Cell count data were gathered from SO/alveus, SP, and SR; $n$ refers to the total number of cells counted from two to four hippocampal sections per tPA ${ }^{\mathrm{BAC}}$-Cer transgenic mouse (lines 863 and 876 ; mice $=$ eight per line). 

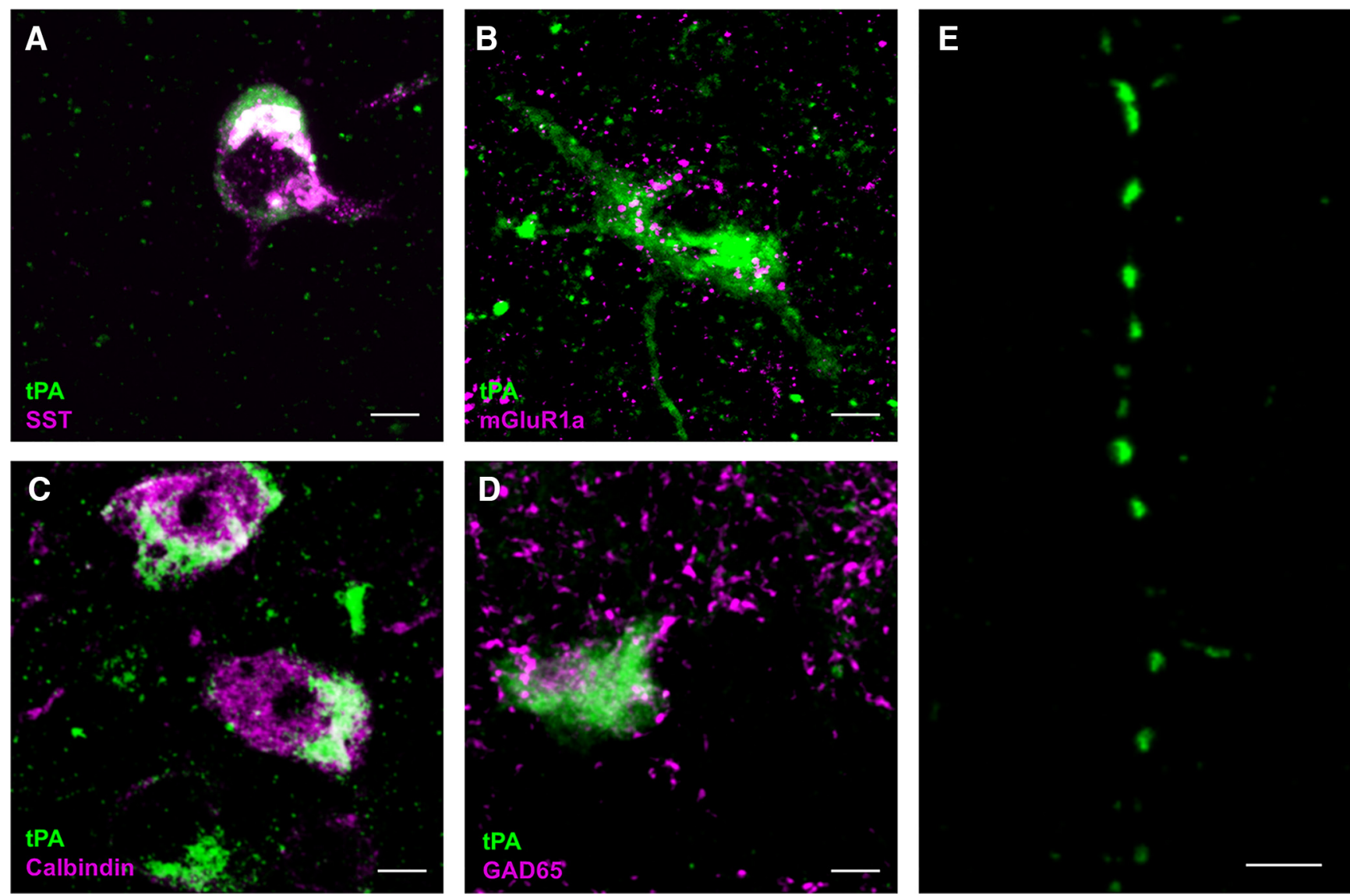

Figure 8. tPA-Cer cells are positive for immunocytochemical markers of O-LM inhibitory interneurons. Dorsal hippocampal sections from tPA $^{\mathrm{BAC}}$-Cer transgenic mice were probed for previously confirmed immunocytochemical markers of O-LM inhibitory interneurons. While O-LM interneurons are known for expressing SST $(\boldsymbol{A})$, other morphologically distinct interneuron subgroups have been shown to stain positive for the neuropeptide. O-LM interneurons, however, have been shown to be strongly decorated with the metabotropic glutamate receptor $1 \mathrm{a}$ (mGluR1a), and they have been shown to express the calcium-binding protein calbindin. High-resolution, confocal images $(63 \times)$ of 10 - $\mu$ m-thick z-stack maximum intensity projections demonstrate that tPA-Cer-positive cells bodies in SO/alveus coexpress both mGluR1a $(\boldsymbol{B})$ and calbindin $(\boldsymbol{C})$. Sections were also stained for GAD65, confirming the GABAergic nature of the tPA-Cer-expressing cells $(\boldsymbol{D})$. In agreement with this, O-LM immunocytochemical profile was the observation of axonal-like projections in SR, as axons of O-LM interneurons extend to stratum lacunosum moleculare (E). Pictures are representative images from SO/alveus of stainings from at least four transgenic mice $(n=4-8)$ per interneuronal marker. mGluR1a, metabotropic glutamate receptor 1a; GAD65, glutamic acid decarboxylase 65. Scale bars: $5 \mu \mathrm{m}(\boldsymbol{A}-\boldsymbol{E})$.

uncoupling most distinctly, tPA's differential expression pattern is also apparent in the amygdala and the basal ganglia. In addition, there is a stark dichotomy between $\beta$-Gal expression and tPA-Cer fluorescence in the cortex and cerebellum. Although $\beta$-Gal is abundant throughout the cortex and cerebellum in Plat $\beta$ GAL reporter mice, other than faintly positive cell bodies in the piriform and entorhinal cortex, there is no detectable tPA-Cer fluorescence in the cortex and cerebellum of $\mathrm{TPA}^{\mathrm{BAC}}$-Cer transgenic mice. Tracing experiments of cortical and cerebellar projections, which are beyond the scope of this article, would help address this discrepancy. For, if tPA is primarily trafficked as our data suggests, then it is possible that tPA-Cer is localized along cortical descending pathways or in efferent targets in the cerebellum, the basal ganglia, the brainstem, and spinal cord. Similarly, more detailed tracing studies would be required to assess if tPA-Cer is localized to cerebellar efferents, like the vestibulocerebellum, spinocerebellum, and cerebrocerebellum pathways, and their target nuclei. Given that tPA's site of action is removed from its site of synthesis, the $\mathrm{PAA}^{\mathrm{BAC}}$-Cer transgenic mice, when analyzed in conjunction with the Plat $\beta$ GAL reporter mice, provide a more informative expression profile of TPA in the adult murine brain.

Taking advantage of the tPA-Cer fusion construct, therefore, we report for the first time tPA's subcellular localization to giant MFBs in stratum lucidum of CA3. Previous studies have only generally described tPA expression in the mossy fiber pathway, without examining its specific compartmentalization. The specific structural localization can potentially provide meaningful insight into tPA's function. This is especially true since mossy fiber axons of DGCs display two other morphologically distinct presynaptic terminals, small en passant boutons and filipodial extensions that emanate from the MFBs (Acsády et al., 1998; Rollenhagen and Lübke, 2010). Moreover, these structurally distinct terminals have divergent postsynaptic targets; MFBs synapse with hilar mossy cells 
and the apical dendritic spines or "thorny excrescences" of CA3 pyramidal cells, while en passant boutons and filipodial extensions preferentially target GABAergic interneurons in the hilus and stratum lucidum (Frotscher et al., 1994; Acsády et al., 1998). The mossy fiber-to-CA3 pyramidal cell synapse also has a different synaptic physiology; compared to the mossy fiber-to-interneuron synapse, the mossy fiber-to-CA3 pyramidal cell synapses shows marked paired-pulse facilitation and LTP (Salin et al., 1996; Henze et al., 2000; Toth et al., 2000; Nicoll and Schmitz, 2005).

Thus, the specific localization of tPA-Cer puncta to giant MFBs suggests that it may have a role in regulating synaptic efficacy at the mossy fiber-to-CA3 pyramidal cell synapse. Consistent with this model, functional studies demonstrate $\mathrm{tPA}^{-/-}$mice to have deficits in LTP in the mossy fiber pathway (Huang et al., 1996). Further interrogations into the mechanism underlying deficits in LTP have focused on a postsynaptic locus of expression. Mice deficient in tPA, which carries a cAMP response element in its promoter, exhibit reduced potentiation by cAMP analogs (Huang et al., 1996); blocking tPA's non-proteolytic interaction with the postsynaptically expressed low-density lipoprotein receptor-related protein (LRP) causes deficits in synaptic potentiation $(\mathrm{Bu}$ et al., 1992; Zhuo et al., 2000); and tPA-mediated cleavage of proBDNF was found to be essential for the full expression of LTP (Korte et al., 1995, 1998; Pang et al., 2004). These mechanistic studies, however, presumed postsynaptic tPA expression and were performed in the hippocampal CA1 region, not at the mossy fiber-to-CA3 pyramidal cell synapse, where we have shown tPA to be most highly expressed in the giant MFBs. Additionally, while amplification of the tPA-Cer signal was able to reveal tPA expression in the soma of CA3 pyramidal cells, high-resolution colocalization analysis did not uncover IPA in the postsynaptic thorny excrescences of CA3 pyramidal cells. In fact, no colocalization was observed between tPA-Cer puncta and the dendritic marker MAP2. Although in vitro studies have shown activity-dependent release of tPA from both pre- and postsynaptic compartments (Gualandris et al., 1996; Lochner et al., 1998, 2006; Scalettar et al., 2012), our in situ expression data demonstrates that tPA's localization is largely presynaptic and suggests that potential presynaptic neuromodulatory effects at the mossy fiber-to-CA3 synapse may have been overlooked.

Interestingly, tPA-Cer puncta were also observed to partially colocalize with astrocytes. It is unclear, however, if the tPA present is endogenous to astrocytes, as transcriptome analysis has shown astrocytes to express IPA mRNA in vitro (Zhang et al., 2014), or if tPA is endocytosed by astrocytes in an LRP-dependent fashion (Cassé et al., 2012). The mossy fiber-to-CA3 pyramidal cell synapse appears unique with respect to its trisynaptic cytoarchitecture. Previous studies indicate that astrocytes completely insulate the synapse, cordoning off the active zone and synaptic cleft from the surrounding parenchyma, but not physically encroaching into the cleft (Rollenhagen et al., 2007). And, while there is no in vivo functional evidence demonstrating the effects of tPA release from astrocytes on synaptic function, in vitro evi- dence has pointed to tPA acting as a gliotransmitter that is released and recycled by astrocytes (Cassé et al., 2012). The lack of perisynaptic astrocytic processes making contact with axon-spine interfaces (Rollenhagen et al., 2007), however, possibly indicates that, at least at the mossy fiber-to-CA3 pyramidal cell synapse, diffusionlimited gliotransmitter tPA may have reduced effects on synaptic function. Moreover, if tPA is released in an activity-dependent manner (Gualandris et al., 1996; Parmer et al., 1997) from giant MFBs, the configuration of the mossy fiber-to-CA3 pyramidal cell synapse suggests that it is not geared toward immediate clearance and uptake, but rather, toward potentiating the effects of tPA and presumably enhancing synaptic efficacy.

In this study, we also identify tPA expression in a subset of SST-positive interneurons in the hippocampal SO/alveus lamina. We provide a detailed distribution of tPACer-positive cell bodies in both the CA1 and CA3 subfields and their quantified coexpression with SSTpositive interneurons. While enhancement of the tPA-Cer protein, with anti-GFP tyramide amplification, was necessary to distinctly visualize these cell bodies, we believe this somatic expression of tPA is physiologic as (1) no signal was observed in littermate transgene negative controls, (2) the recapitulation of tPA expression in the mossy fiber pathway indicates that tPA-Cer is appropriately targeted to its cellular and subcellular locale, and (3) $\beta$-GAL puncta in the Plat $\beta$ GAL reporter mice are noticeable in SO/alveus and SR (Fig. 2). Presumably, the increase in tPA expression, due to extra copy number from the BAC transgene, allowed for the detection of a previously unrecognized and specific population of tPA-expressing cells. It is unclear, however, why tPA is differentially localized to the soma or axonal projection and if such differential trafficking is functionally significant. For, tPA appears to be largely localized to the soma of inhibitory interneurons (Fredriksson et al., 2015) and to the axons of excitatory neurons (Louessard et al., 2015). While knowledge about dense core vesicle trafficking is still nascent compared to synaptic vesicle trafficking, there is evidence which demonstrates regionally-specific, differential trafficking of the neuropeptide NPY to dendrites and axons (Ramamoorthy et al., 2011) and that excitatory and inhibitory neurons in the hippocampus exhibit different dense core vesicle molecular machinery (Ramírez-Franco et al., 2016).

In the CA1 hippocampal region alone, more than a dozen different types of interneurons have been classified based on their morphologic, neurochemical and physiologic properties (Freund and Buzsáki, 1996; Somogyi and Klausberger, 2005). And, while no one single marker is indicative of a specific type of interneuron, tPA-Cerpositive cells appear to share a very similar somatic distribution (Oliva et al., 2000) and immunocytochemical profile with O-LM interneurons (Somogyi and Klausberger, 2005; Minneci et al., 2007; Sylwestrak and Ghosh, 2012). As tPA-expressing neurons have never been described in SST/O-LM interneurons before, it is unclear how IPA may be exerting its effects. Morphologically, the axonal projections of O-LM interneurons ramify at the 
distal apical dendrites of CA1 pyramidal cells, where perforant path fibers from the entorhinal cortex terminate. Functionally, O-LM interneurons are known to fire rhythmically at the trough of theta $(4-8 \mathrm{~Hz})$ oscillations in the hippocampus (Klausberger et al., 2003), and they have been shown to facilitate LTP in the Schaffer collateral-toCA1 pathway. Although deficiency in IPA has been previously implicated in defects in the late-phase of LTP in the hippocampal CA1 region (Huang et al., 1996; Calabresi et al., 2000), the contribution of tPA from O-LM interneurons has not been specifically tested in this paradigm. Plasticity of glutamatergic CA1 synapses onto O-LM interneurons has also been investigated, as changes in synaptic efficacy may have an important role in modulating network excitability (Nicholson and Kullmann, 2014). To date, however, it is unknown if tPA is involved in these events.

Taken together, the regional, cellular, and subcellular characterization of TPA expression presented here provides a primer on tPA's role in the CNS. Many of the foundational experiments on tPA's function in the brain were performed before a detailed description of its protein localization, this is especially confounding in the case of tPA as its site of synthesis is uncoupled from it targeted site of action. With the generation of the $\mathrm{TPA}^{\mathrm{BAC}}-\mathrm{Cer}$ transgenic mice and its appropriately targeted tPA-Cer fusion protein, however, future mechanistic studies to elucidate tPA's function are now possible.

\section{References}

Acsády L, Kamondi A, Sı”k A, Freund T, Buzsáki G (1998) GABAergic cells are the major postsynaptic targets of mossy fibers in the rat hippocampus. J Neurosci 18:3386-3403. Medline

Ahmed N, Wahlgren N, Grond M, Hennerici M, Lees KR, Mikulik R, Parsons M, Roine RO, Toni D, Ringleb P (2010) Implementation and outcome of thrombolysis with alteplase 3-4.5 h after an acute stroke: an updated analysis from SITS-ISTR. Lancet Neurol 9:866874. CrossRef Medline

Akassoglou K, Kombrinck KW, Degen JL, Strickland S (2000) Tissue plasminogen activator-mediated fibrinolysis protects against axonal degeneration and demyelination after sciatic nerve injury. $J$ Cell Biol 149:1157-1166. Medline

Babaev O, Chatain CP, Krueger-Burg D (2018) Inhibition in the amygdala anxiety circuitry. Exp Mol Med 50:18. CrossRef

Bolte S, Cordelières FP (2006) A guided tour into subcellular colocalization analysis in light microscopy. J Microsc 224:213-232. CrossRef Medline

Bu G, Williams S, Strickland DK, Schwartz AL (1992) Low density lipoprotein receptor-related protein/alpha 2-macroglobulin receptor is an hepatic receptor for tissue-type plasminogen activator. Proc Natl Acad Sci USA 89:7427-7431. CrossRef

Calabresi P, Napolitano M, Centonze D, Marfia GA, Gubellini P, Teule MA, Berretta N, Bernardi G, Frati L, Tolu M, Gulino A (2000) Tissue plasminogen activator controls multiple forms of synaptic plasticity and memory. Eur J Neurosci 12:1002-1012. Medline

Carroll PM, Tsirka SE, Richards WG, Frohman MA, Strickland S (1994) The mouse tissue plasminogen activator gene 5' flanking region directs appropriate expression in development and seizureenhanced response in the CNS. Development 120:3173-3183. Medline

Cassé F, Bardou I, Danglot L, Briens A, Montagne A, Parcq J, Alahari A, Galli T, Vivien D, Docagne F (2012) Glutamate controls tPA recycling by astrocytes, which in turn influences glutamatergic signals. J Neurosci 32:5186-5199. CrossRef Medline
Costes SV, Daelemans D, Cho EH, Dobbin Z, Pavlakis G, Lockett S (2004) Automatic and quantitative measurement of protein-protein colocalization in live cells. Biophys J 86:3993-4003. CrossRef Medline

Dunn KW, Kamocka MM, McDonald JH (2011) A practical guide to evaluating colocalization in biological microscopy. Am J Physiol Cell Physiol 300:C723-C742. CrossRef Medline

Fredriksson L, Stevenson TK, Su EJ, Ragsdale M, Moore S, Craciun S, Schielke GP, Murphy GG, Lawrence DA (2015) Identification of a neurovascular signaling pathway regulating seizures in mice. Ann Clin Trans Neurol 2:722-738. CrossRef

Freund TF, Buzsáki G (1996) Interneurons of the hippocampus. Hippocampus 6:347-470. CrossRef Medline

Frey U, Müller M, Kuhl D (1996) A different form of long-lasting potentiation revealed in tissue plasminogen activator mutant mice. J Neurosci 16:2057-2063. Medline

Frotscher M, Soriano E, Misgeld U (1994) Divergence of hippocampal mossy fibers. Synapse 16:148-160. CrossRef Medline

Gilman S, Newman SW (2002) Manter and Gatz's essentials of clinical neuroanatomy and neurophysiology, Ed 10. Philadelphia, PA: F.A. Davis Company. CrossRef

Gualandris A, Jones TE, Strickland S, Tsirka SE (1996) Membrane depolarization induces calcium-dependent secretion of tissue plasminogen activator. J Neurosci 16:2220-2225. Medline

Hammer KH, Klingberg F (1990) Active avoidance is permanently abolished after lesions of the nucleus interpeduncularis in rat. Biomed Biochim Acta 49:489-497. Medline

Henze DA, Urban NN, Barrionuevo G (2000) The multifarious hippocampal mossy fiber pathway: a review. Neuroscience 98:407427. Medline

Huang YY, Bach ME, Lipp H, Zhuo M, Wolfer DP, Hawkins RD, Schoonjans L, Kandel ER, Godfraind JM, Mulligan R, Collen D, Carmeliet P (1996) Mice lacking the gene encoding tissue-type plasminogen activator show a selective interference with latephase long-term potentiation in both Schaffer collateral and mossy fiber pathways. Proc Natl Acad Sci USA 93:8699-8704. Medline

Huarte J, Belin D, Vassalli J (1985) Plasminogen activator in mouse and rat oocytes: induction during meiotic maturation. Cell 43:551558. Medline

Jahanshahi M, Obeso I, Rothwell JC, Obeso JA (2015) A frontostriato-subthalamic-pallidal network for goal-directed and habitual inhibition. Nat Rev Neurosci 16:719-732. Medline

Janak PH, Tye KM (2015) From circuits to behavior in the amygdala. Nature 517:284-292. CrossRef Medline

Klausberger T, Magill PJ, Márton LF, Roberts JD, Cobden PM, Buzsáki G, Somogyi P (2003) Brain-state- and cell-type-specific firing of hippocampal interneurons in vivo. Nature 421:844-848. CrossRef Medline

Korte M, Carroll P, Wolf E, Brem G, Thoenen H, Bonhoeffer T (1995) Hippocampal long-term potentiation is impaired in mice lacking brain-derived neurotrophic factor. Proc Natl Acad Sci USA 92: 8856-8860. Medline

Korte M, Kang H, Bonhoeffer T, Schuman E (1998) A role for BDNF in the late-phase of hippocampal long-term potentiation. Neuropharmacology 37:553-559. Medline

Krueger SR, Ghisu G, Cinelli P, Gschwend TP, Osterwalder T, Wolfer DP, Sonderegger P (1997) Expression of neuroserpin, an inhibitor of tissue plasminogen activator, in the developing and adult nervous system of the mouse. J Neurosci 17:8984-8996. Medline

Krystosek A, Seeds NW (1981) Plasminogen activator release at the neuronal growth cone. Science 213:1532-1534. Medline

Liao MC, Muratore CR, Gierahn TM, Sullivan SE, Srikanth P, De Jager PL, Love JC, Young-Pearse TL (2016) Single-cell detection of secreted A $\beta$ and SAPP $\alpha$ from human IPSC-derived neurons and astrocytes. J Neurosci 36:1730-1746. CrossRef Medline

Lochner JE, Kingma M, Kuhn S, Meliza CD, Cutler B, Scalettar BA (1998) Real-time imaging of the axonal transport of granules containing a tissue plasminogen activator/green fluorescent protein hybrid. Mol Biol Cell 9:2463-2476. Medline 
Lochner JE, Honigman LS, Grant WF, Gessford SK, Hansen AB, Silverman MA, Scalettar BA (2006) Activity-dependent release of tissue plasminogen activator from the dendritic spines of hippocampal neurons revealed by live-cell imaging. J Neurobiol 66: 564-577. CrossRef

Lochner JE, Spangler E, Chavarha M, Jacobs C, McAllister K, Schuttner LC, Scalettar BA (2008) Efficient copackaging and cotransport yields postsynaptic colocalization of neuromodulators associated with synaptic plasticity. Dev Neurobiol 68:1243-1256. CrossRef Medline

Louessard M, Lacroix A, Martineau M, Mondielli G, Montagne A, Lesept F, Lambolez B, Cauli B, Mothet JP, Vivien D, Maubert E (2016) Tissue plasminogen activator expression is restricted to subsets of excitatory pyramidal glutamatergic neurons. Mol Neurobiol 53:5000-5012. CrossRef

Matys T, Pawlak R, Matys E, Pavlides C, McEwen BS, Strickland S (2004) Tissue plasminogen activator promotes the effects of corticotropin-releasing factor on the amygdala and anxiety-like behavior. Proc Natl Acad Sci USA 101:16345-16350. CrossRef Medline

Minneci F, Janahmadi M, Migliore M, Dragicevic N, Avossa D, Cherubini $E$ (2007) Signaling properties of stratum oriens interneurons in the hippocampus of transgenic mice expressing EGFP in a subset of somatostatin-containing cells. Hippocampus 17:538-553. CrossRef

Nicole O, Docagne F, Ali C, Margaill I, Carmeliet P, MacKenzie ET, Vivien D, Buisson A (2001) The proteolytic activity of tissueplasminogen activator enhances NMDA receptor-mediated signaling. Nat Med 7:59-64. CrossRef Medline

Nicoll RA, Schmitz D (2005) Synaptic plasticity at hippocampal mossy fibre synapses. Nat Rev Neurosci 6:863-876. CrossRef Medline

Nicholson E, Kullmann DM (2014) Long-term potentiation in hippocampal oriens interneurons: postsynaptic induction, presynaptic expression and evaluation of candidate retrograde factors. Philos Trans R Soc Lond B Biol Sci 369:20130133.

Oliva AA, Jiang M, Lam T, Smith KL, Swann JW (2000) Novel hippocampal interneuronal subtypes identified using transgenic mice that express green fluorescent protein in GABAergic interneurons. J Neurosci 20:3354-3368. Medline

Pang PT, Teng HK, Zaitsev E, Woo NT, Sakata K, Zhen S, Teng KK, Yung WH, Hempstead BL, Lu B (2004) Cleavage of proBDNF by tPA/plasmin is essential for long-term hippocampal plasticity. Science 306:487-491. CrossRef Medline

Park L, Gallo EF, Anrather J, Wang G, Norris EH, Paul J, Strickland S, ladecola C (2008) Key role of tissue plasminogen activator in neurovascular coupling. Proc Natl Acad Sci USA 105:1073-1078. CrossRef Medline

Parmer RJ, Mahata M, Mahata S, Sebald MT, O'Connor DT, Miles LA (1997) Tissue plasminogen activator (t-PA) is targeted to the regulated secretory pathway. Catecholamine storage vesicles as a reservoir for the rapid release of t-PA. J Biol Chem 272:19761982. Medline

Pawlak R, Nagai N, Urano T, Napiorkowska-Pawlak D, Ihara H, Takada Y, Collen D, Takada A (2002) Rapid, specific and active site-catalyzed effect of tissue-plasminogen activator on hippocampusdependent learning in mice. Neuroscience 113:995-1001. Medline

Pawlak R, Magarinos AM, Melchor J, McEwen B, Strickland S (2003) Tissue plasminogen activator in the amygdala is critical for stressinduced anxiety-like behavior. Nat Neurosci 6:168-174. CrossRef Medline

Penzo MA, Robert V, Tucciarone J, De Bundel D, Wang M, Van Aelst L, Darvas M, Parada LF, Palmiter RD, He M, Huang ZJ, Li B (2015) The paraventricular thalamus controls a central amygdala fear circuit. Nature 519:455-459. CrossRef

Prabhakaran S, Ruff I, Bernstein RA (2015) Acute stroke intervention: a systematic review. JAMA 313:1451-1462. CrossRef Medline

Purves D, Augustine GJ, Fitzpatrick D, Katz LC, LaMantia AS, McNamara JO, Williams SM (2001) Modulation of movement by the basal ganglia. In: Neuroscience, Ed 2, pp 417-433. Sunderland, MA: Sinauer Associates. CrossRef

Qian Z, Gilbert ME, Colicos MA, Kandel ER, Kuhl D (1993) Tissueplasminogen activator is induced as an immediate-early gene during seizure, kindling and long-term potentiation. Nature 361: 453-457. CrossRef Medline

Ramamoorthy P, Wang Q, Whim MD (2011) Cell type-dependent trafficking of neuropeptide $\mathrm{Y}$-containing dense core granules in CNS neurons. J Neurosci 31:14783-14788. CrossRef Medline

Ramírez-Franco JJ, Munoz-Cuevas FJ, Luján R, Jurado S (2016) Excitatory and inhibitory neurons in the hippocampus exhibit molecularly distinct large dense core vesicles. Front Cell Neurosci 10:202. CrossRef Medline

Rizzo MA, Springer GH, Granada B, Piston DW (2004) An improved cyan fluorescent protein variant useful for FRET. Nat Biotechnol 22:445-449. CrossRef Medline

Rollenhagen A, Lübke JH (2010) The mossy fiber bouton: the "common" or the "unique" synapse? Front Synaptic Neurosci 2:2. CrossRef Medline

Rollenhagen A, Sätzler K, Rodríguez EP, Jonas P, Frotscher M, Lübke JH (2007) Structural determinants of transmission at large hippocampal mossy fiber synapses. J Neurosci 27:10434-10444. CrossRef Medline

Sandercock P, Wardlaw JM, Lindley RI, Dennis M, Cohen G, Murray G, Innes K, Venables G, Czlonkowska A, Kobayashi A, Ricci S, Murray V, Berge E, Slot KB, Hankey GJ, Correia M, Peeters A, Matz K, Lyrer P, Gubitz G, et al. (2012) The benefits and harms of intravenous thrombolysis with recombinant tissue plasminogen activator within $6 \mathrm{~h}$ of acute ischaemic stroke (the third international stroke trial [IST-3]): a radmonised controlled trial. Lancet 379:2352-2363. CrossRef Medline

Salin PA, Scanziani M, Malenka RC, Nicoll RA (1996) Distinct shortterm plasticity at two excitatory synapses in the hippocampus. Proc Natl Acad Sci USA 93:13304-13309. Medline

Salles FJ, Strickland S (2002) Localization and regulation of the tissue plasminogen activator-plasmin system in the hippocampus. J Neurosci 22:2125-2134. Medline

Sappino AP, Madani R, Huarte J, Belin D, Kiss JZ, Wohlwend A, Vassalli J (1993) Extracellular proteolysis in the adult murine brain. J Clin Invest 92:679-685. CrossRef Medline

Scalettar BA, Jacobs C, Fulwiler A, Prahl L, Simon A, Hilken L, Lochner JE (2012) Hindered submicron mobility and long-term storage of presynaptic dense-core granules revealed by singleparticle tracking. Dev Neurobiol 72:1181-1195. CrossRef

Schindelin J, Arganda-Carreras I, Frise E, Kaynig V, Longair M, Pietzsch T, Preibisch S, Rueden C, Saalfeld S, Schmid B, Tinevez JY, White DJ, Hartenstein V, Eliceiri K, Tomancak P, Cardona A (2012) Fiji: an open-source platform for biological-image analysis. Nat Methods 28:676-682. CrossRef

Schmid B, Schindelin J, Cardona A, Longair M, Heisenberg M (2010) A high-level 3D visualization API for Java and ImageJ. BMC Bioinformatics 11:274. CrossRef Medline

Shin CY, Kundel M, Wells DG (2004) Rapid, activity-induced increase in tissue plasminogen activator is mediated by metabotropic glutamate receptor-dependent mRNA translation. J Neurosci 24: 9425-9433. CrossRef Medline

Siao C, Fernandez SR, Tsirka SE (2003) Cell type-specific roles for tissue plasminogen activator released by neurons or microglia after excitotoxic injury. J Neurosci 23:3234-3242. Medline

Silverman MA, Johnson S, Gurkins D, Farmer M, Lochner JE, Rosa P, Scalettar BA (2005) Mechanisms of transport and exocytosis of dense-core granule containing tissue plasminogen activator in developing hippocampal neurons. J Neurosci 25:3095-3106. CrossRef Medline

Somogyi P, Klausberger T (2005) Defined types of cortical interneurone structure space and spike timing in the hippocampus. J Physiol 562:9-26. CrossRef Medline

Su EJ, Fredriksson L, Geyer M, Folestad E, Cale J, Andrae J, Gao Y, Pietras K, Mann K, Yepes M, Strickland DK, Betsholtz C, Eriksson U, Lawrence DA (2008) Activation of PDGF-CC by tissue plasmin- 
ogen activator impairs blood-brain barrier integrity during ischemic stroke. Nat Med 14:731-737. CrossRef Medline

Sylwestrak EL, Ghosh A (2012) Elfn1 regulates target-specific release probability at CA1-interneuron synapses. Science 338:536540. CrossRef Medline

Tasan RO, Verma D, Wood J, Lach G, Hörmer B, de Lima TCM, Herzog H, Sperk G (2016) The role of neuropeptide $Y$ in fear conditioning and extinction. Neuropeptides 55:111-126. CrossRef

Toth K, Suares G, Lawrence JJ, Philips-Tansey E, McBain CJ (2000) Differential mechanisms of transmission at three types of mossy fiber synapse. J Neurosci 20:8279-8289. Medline

Tsirka SE, Gualandris A, Amaral DG, Strickland S (1995) Excitotoxininduced neuronal degeneration and seizure are mediated by tissue plasminogen activator. Nature 377:340-344. CrossRef Medline

Van Keuren ML, Gavrilina GB, Filipiak WE, Zeidler MG, Saunders TL (2009) Generating transgenic mice from bacterial artificial chromosomes: transgenesis efficiency, integration and expression outcomes. Transgenic Res 18:769-785. CrossRef Medline

Wenzel HJ, Cole TB, Born DE, Schwartzkroin PA, Palmiter RD (1997) Ultrastructural localization of zing transporter-3 (ZnT-3) to synaptic vesicle membranes within mossy fiber boutons in the hippocampus of mouse and monkey. Proc Natl Acad Sci USA 94:1267612681. CrossRef
Wu F, Torre E, Cuellar-Giraldo D, Cheng L, Yi H, Bichler EK, García PS, Yepes M (2015) Tissue-type plasminogen activator triggers the synaptic vesicle cycle in cerebral cortical neurons. J Cereb Blood Flow Metab 35:1966-1976. CrossRef Medline

Yu H, Schleuning WD, Michl M, Liberatore G, Tan SS, Medcalf RL (2001) Control elements between -9.5 and $-3.0 \mathrm{~kb}$ in the human tissue-type plasminogen activator gene promoter direct spatial and inducible expression to the murine brain. Eur $\mathrm{J}$ Neurosci 14:799-808. Medline

Zhang Y, Chen K, Sloan SA, Bennett ML, Scholze AR, O'Keeffe S, Phatnani HP, Guarnieri P, Caneda C, Ruderisch N, Deng S, Liddelow SA, Zhang C, Daneman R, Maniatis T, Barres BA, Wu JQ (2014) An RNA-sequencing transcriptome and splicing database of glia, neurons, and vascular cells of the cerebral cortex. J Neurosci 34:11929-11947. CrossRef

Zhuo M, Holtzman DM, Li Y, Osaka H, DeMaro J, Jacquin M, Bu G (2000) Role of tissue plasminogen activator receptor LRP in hippocampal long-term potentiation. J Neurosci 20:542-549. Medline

Zou T, Ling C, Xiao Y, Tao X, Ma D, Chen ZL, Strickland S, Song H (2006) Exogenous tissue plasminogen activator enhances peripheral nerve regeneration and functional recovery after injury in mice. J Neuropath Exp Neurol 65:78-86. Medline 